CYNTHIA ELISA WIDMER

Perfil sanitário de onças-pintadas (Panthera onca) de vida livre no Pantanal Sul do Mato Grosso do Sul - Brasil 


\section{Perfil sanitário de onças-pintadas (Panthera onca) de vida livre no Pantanal Sul do Mato Grosso do Sul - Brasil}

Dissertação apresentada ao Programa de PósGraduação em Epidemiologia Experimental Aplicada às Zoonoses da Faculdade de Medicina Veterinária e Zootecnia da Universidade de São Paulo para obtenção do título de Mestre em Ciências

\section{Departamento:}

Medicina Veterinária Preventiva e Saúde Animal

Área de concentração:

Epidemiologia Experimental Aplicada às Zoonoses

Orientador:

Prof. Dr. Fernando Ferreira

São Paulo 
Autorizo a reprodução parcial ou total desta obra, para fins acadêmicos, desde que citada a fonte.

DADOS INTERNACIONAIS DE CATALOGAÇÃO-NA-PUBLICAÇÃO

(Biblioteca Virginie Buff D’Ápice da Faculdade de Medicina Veterinária e Zootecnia da Universidade de São Paulo)

Perfil sanitário de onças-pintadas (Panthera onca) de vida livre no Pantanal Sul do Mato Grosso do Sul - Brasil / Cynthia Elisa Widmer. - 2009. 89 f. : il.

Dissertação (Mestrado) - Universidade de São Paulo. Faculdade de Medicina Veterinária e Zootecnia. Departamento de Medicina Veterinária Preventiva e Saúde Animal, São Paulo, 2009.

Programa de Pós-Graduação: Epidemiologia Experimental Aplicada às Zoonoses.

Área de concentração: Epidemiologia Experimental Aplicada às Zoonoses.

Orientador: Prof. Dr. Fernando Ferreira.

1. Panthera onca. 2. Saúde animal. 3. Raiva. 4. Carrapatos. 5. Doenças infecciosas em animais. I. Título. 
PARECER DA COMISSÃO DE BIOÉTICA

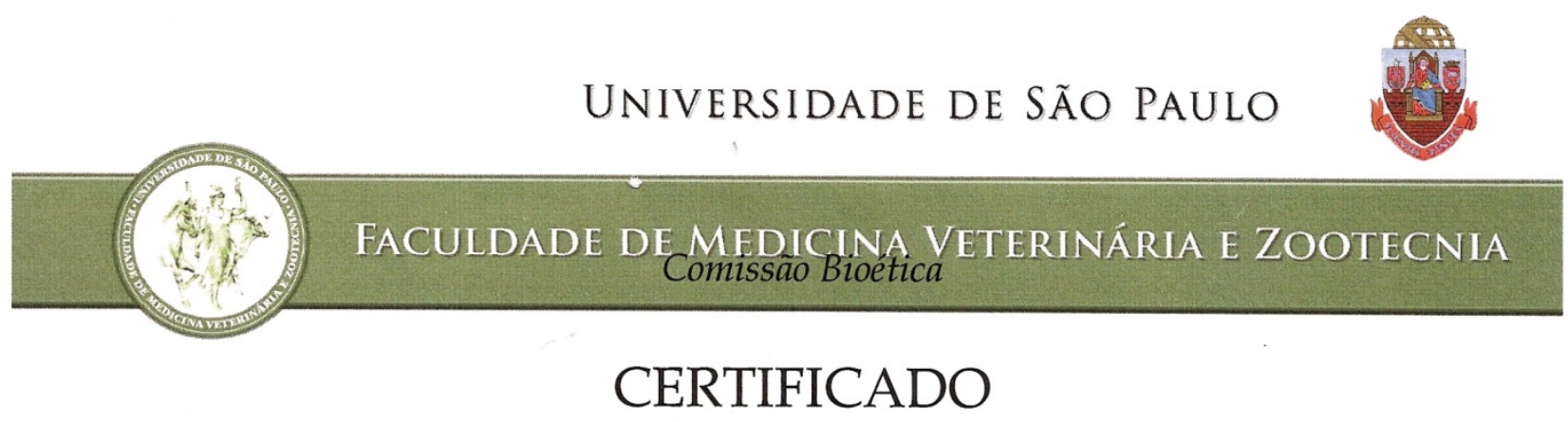

Certificamos que o Projeto intitulado "Perfil sanitário de onças-pintadas (Panthera onca) de vida livre no Pantanal Sul do Mato Grosso do Sul - Brasil", protocolado sob o n⿳1531/2008, utilizando 10 (dez) onças-pintadas, sob a responsabilidade do Prof. Dr. Fernando Ferreira, está de acordo com os princípios éticos de experimentação animal da Comissão de Bioética da Faculdade de Medicina Veterinária e Zootecnia da Universidade de São Paulo e foi aprovado em reunião de $11 / 02 / 09$.

(We certify that the Research "Sanitary profile of free-ranging jaguars (Panthera onca) in the Brazilian Pantanal, Mato Grosso do Sul - State", protocol number 1531/2008, utilizing 10 (ten) jaguars, under the responsibility Prof. Dr. Fernando Ferreira, agree with Ethical Principles in Animal Research adopted by Bioethic Commission of the School of Veterinary Medicine and Zootechny of University of São Paulo and was approved in the meeting of day 02/11/09).

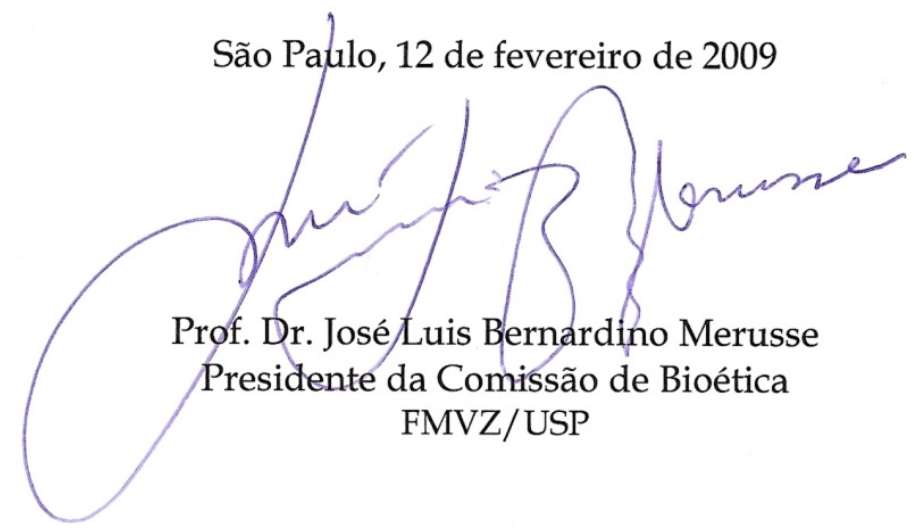




\section{FOLHA DE AVALIAÇÃO}

Nome: WIDMER, Cynthia Elisa

Título: Perfil sanitário de onças-pintadas (Panthera onca) de vida livre no Pantanal Sul do Mato Grosso do Sul - Brasil

Dissertação apresentada ao Programa de PósGraduação em Epidemiologia Experimental Aplicada às Zoonoses da Faculdade de Medicina Veterinária e Zootecnia da Universidade de São Paulo para obtenção do título de Mestre em Ciências

Data:

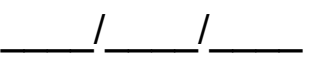

\section{Banca Examinadora}

Prof. Dr. Instituição:

Assinatura: Julgamento:

Prof. Dr. Instituição:

Assinatura: Julgamento:

Prof. Dr. Instituição:

Assinatura: Julgamento: 


\section{DEDICATÓRIA}

Dedico esta dissertação a todas as pessoas que, mesmo não sabendo, tanto me inspiraram para realizar este trabalho. 


\section{AGRADECIMENTOS}

Gostaria de agradecer ao Instituto Pró-Carnívoros - especialmente à Juliana Demori -, à Fazenda Real Filial São Bento, ao CENAP/ICMBio - especialmente ao chefe deste centro, Ronaldo Morato - e ao WWF-Brasil por todo o apoio e/ou financiamento ao Projeto Onça Pantaneira, sem o qual este subprojeto não teria acontecido.

Agradeço também à Fundação de Amparo à Pesquisa do Estado de São Paulo (FAPESP), por acreditar em meu projeto e disponibilizar a bolsa (processo 2008/02573-0).

Ao professor Leonardo Richtzenhain por disponibilizar o serviço de sequenciamento genético de seu laboratório e à Sheila por realizá-los.

Ao Instituto Pasteur de São Paulo, especialmente à Dra. Ivanete Kotait e à Dra. Karin Ferreira, por possibilitar a sorologia para raiva nas amostras das onças-pintadas capturadas.

Ao Dr. Reginaldo e Dr. Cesar do Laboratório Carlos Chagas, por todas as sugestões e amostras processadas fora de hora.

Ao pessoal da biblioteca da FMVZ/USP e à Tânia da Pós-Graduação, pelo apoio na fase final da dissertação.

Ao professor Fernando Ferreira, por ter aceito ser meu orientador.

À Jucélia e demais integrantes do LEB, por sempre me receberem tão bem nas vezes em que estive no laboratório.

Aos funcionários da Fazenda São Bento - Célio, Vanderlei, Cristiane, Sr. Ormir, Paulo e todos os outros - pelo apoio ao projeto, e especialmente à dona Leda, por sempre ter uma comida gostosa e quentinha a nossa espera após as longas horas de trabalho.

À equipe do Projeto Onça Pantaneira - João, Henrique e Alexandre - pelas muitas horas boas e difíceis compartilhadas a campo, muito obrigada por tudo o que me ensinaram.

Aos veterinários Tatiana Ono e Rodrigo Jorge por participarem das capturas enquanto eu cumpria outras obrigações da pós-graduação. Ao Rodrigo também meu agradecimento por tanto ter colaborado para a elaboração deste projeto e dos protocolos de coleta de amostras.

Ao professor Marcelo Bahia Labruna, por todo o material, tempo e atenção dedicados a este projeto. Agradeço também as muitas aulas sobre carrapatos e seus patógenos e a paciência para responder tantas perguntas.

Ao pessoal do Laboratório Carrapatos que tanto me ajudaram nas análises das amostras e que tornaram as horas de trabalho no laboratório agradáveis e por vezes até divertidas. Especialmente agradeço ao Richard, Thiago, lara, Jonas, Fernanda, Mariana, Lili, Thaís, Maria, Guilherme, Hilda e Renato.

Ao pessoal do Laboratório de Ecologia Animal da ESALQ, especialmente ao prof. Luciano Verdade e à Carla Gheler, por todas as ajudas e conversas.

Aos meus amigos que, de longe ou de perto, entendendo ou não meu trabalho, sempre me apoiaram. E como com vocês tenho liberdade suficiente, não vou arriscar listar os nomes, vocês sabem que com certeza esqueceria algum...

Às minhas famílias adotivas ao longo do mestrado, Dedé e Quel, Xande, Gi e Fabi, não tenho palavras para agradecer todo o carinho e ajuda que vocês me deram.

Ao meu pai pelas muitas conversas e por todo o amor demonstrado.

À minha mãe por sua imensa paciência e por todo o amor que sempre me deu, você é sem dúvida a pessoa que mais me ajudou a chegar até aqui.

Ao Fernando, por ser muito mais que namorado ou colega de trabalho, por ser esta pessoa que eu tanto amo e admiro.

A Deus, que me proporcionou tantos momentos felizes e anjos para os momentos difíceis. 


\section{RESUMO}

WIDMER, C. E. Perfil sanitário de onças-pintadas (Panthera onca) de vida livre no Pantanal Sul do Mato Grosso do Sul - Brasil. [Health profile of free-ranging jaguars (Panthera onca) in Pantanal, Mato Grosso do Sul State - Brazil]. 2009. 89f. Dissertação (Mestrado em Ciências) - Faculdade de Medicina Veterinária e Zootecnia, Universidade de São Paulo, São Paulo, 2009.

Poucos são os estudos acerca da saúde de onças-pintadas em vida livre. Visando obter melhores parâmetros para avaliação clínica desta espécie ameaçada de extinção, foram realizados exame clínico, hemograma, perfil bioquímico e acompanhamento de 10 onças-pintadas da região de Corumbá, no Pantanal do Mato Grosso do Sul. Além disso, buscando obter informações sobre o possível papel da espécie como suscetível, hospedeira ou sentinela de patógenos de importância em saúde pública e animal, amostras destas 10 onças foram testadas através de métodos sorológicos para verificar contato com vírus rábico, Rickettsia spp. e Ehrlichia canis. As amostras das onças e os carrapatos que as parasitavam no momento das capturas foram testados por reação em cadeia pela polimerase para a família Anaplasmataceae e os gêneros Rickettsia, Borrelia, Coxiella, Hepatozoon e Babesia. Este é o primeiro estudo a relatar os valores de hemograma e perfil bioquímico de uma população de onças-pintadas de vida livre. Dois animais, assintomáticos, apresentaram baixo título sorológico para o vírus da raiva, sugerindo contato da espécie com este patógeno. Todas as onças capturadas foram consideradas soropositivas para Rickettsia spp., e Rickettsia parkeri foi sequenciada a partir de um Amblyomma triste que estava parasitando um dos animais. Foi descoberta uma possível nova espécie do gênero Ehrlichia através do sequenciamento de DNA obtido de um Amblyomma triste e um Amblyomma cajenense que estavam parasitando onças. Quatro onças-pintadas foram consideradas soropositivas para Ehrlichia canis, possivelmente uma reação cruzada com esta outra espécie. Todas as onças-pintadas avaliadas neste estudo apresentaram DNA de Cytauxzoon sp., com 98\% de similaridade a C. felis, em amostras sanguíneas. Todas as onças avaliadas neste estudo apresentaram DNA de Hepatozoon sp., com $98 \%$ de similaridade a $\mathrm{H}$. felis, em amostras sanguíneas. As onças apresentavam boas condições de saúde geral.

Palavras-chave: Panthera onça. Saúde animal. Raiva. Carrapatos. Doenças Infecciosas em Animais. 


\section{ABSTRACT}

WIDMER, C. E. Health profile of free-ranging jaguars (Panthera onca) in Pantanal, Mato Grosso do Sul State - Brazil. [Perfil sanitário de onças-pintadas (Panthera onca) de vida livre no Pantanal Sul do Mato Grosso do Sul - Brasil]. 2009. 89 f. Dissertação (Mestrado em Ciências) - Faculdade de Medicina Veterinária e Zootecnia, Universidade de São Paulo, São Paulo, 2009.

Few studies have been conducted to investigate the health of free-ranging jaguars. In order to obtain better parameters for clinical evaluation of this endangered species, clinical exams, hemogram, biochemical tests and ecological monitoring were done for 10 jaguars in the Pantanal region - Corumbá City, Mato Grosso do Sul State. This project also evaluated the possible role of this species as susceptible, host or sentinel for pathogens of public and/or animal health importance, testing samples from these animals by serological methods to rabies virus, Rickettsia spp. and Ehrlichia canis. All samples and all ticks collected from the jaguars were also tested by polymerase chain reaction to the Anaplasmataceae family and the genera Rickettsia, Borrelia, Coxiella, Hepatozoon and Babesia. This is the first report of hemograms and biochemical profile of a free-ranging jaguar population. Two asymptomatic animals presented low seropositivity for rabies virus, suggesting contact with this pathogen. All jaguars were considered seropositive for Rickettsia spp., and Rickettsia parkeri was sequenced from an Amblyomma triste that was parasitizing one of the animals. A possible new species of the genus Ehrlichia has been identified by DNA sequencing obtained from an Amblyomma triste and an Amblyomma cajenense that were parasitizing jaguars. Four jaguars were considered seropositive for Ehrlichia canis, possibly a cross-reaction with this other species. All jaguars evaluated in this study presented DNA fragments of Cytauxzoon sp., 98\% similarity to $C$. felis in blood samples. In addition, all jaguars presented DNA fragments of Hepatozoon sp., $98 \%$ similarity to $H$. felis in blood samples. In general, these jaguars presented good health.

Keywords: Panthera onca. Animal health. Rabies. Ticks. Tick-borne diseases. 


\section{LISTA DE ABREVIATURAS E SIGLAS}

$\mu \mathrm{g} \quad$ micrograma

ul microlitro

ALT alanina aminotransferase

AST aspartato aminotransferase

CDV vírus da cinomose canina

CHCM concentração de hemoglobina corpuscular média

CPK creatinofosfoquinase

dl decilitro

DNA deoxyribonucleic acid - ácido desoxiribonucleico

EDTA ácido etilodiaminotetracético

ELISA enzyme linked immuno sorbent assay - ensaio imunoenzimático

ESALQ Escola Superior de Agricultura Luiz de Queiroz

FA fosfatase alcalina

fl fentolitros

FMVZ Faculdade de Medicina Veterinária e Zootecnia

g gramas

$g$ força da gravidade

GFM Grupo da Febre Maculosa

GGT gama glutamil transferase

GPS global positioning system - sistema de posicionamento global

GT Grupo do Tifo

HCM hemoglobina corpuscular média

IBAMA Instituto Brasileiro do Meio Ambiente e dos Recursos Naturais Renováveis

IgG imunoglobulina $\mathrm{G}$

$\mathrm{Kg}$ quilograma

km quilômetro

L litro

mg miligrama

$\mathrm{ml} \quad$ mililitro

$\mathrm{mm} \quad$ milímetro

MS Mato Grosso do Sul

OIE Organização Mundial da Saúde Animal 
PBS phosphate buffered saline solution - solução salina fosfatada tamponada

PCR reação em cadeia pela polimerase

pg picograma

RIFI reação de imunofluorescência indireta

rpm rotações por minuto

SFMIT Microteste de Inibição de Fluorescência Simplificado

TE tris EDTA

TBE tris borato EDTA

$\mathrm{U} \quad$ unidades

UI unidades internacionais

USP Universidade de São Paulo

VCM volume corpuscular médio

VHS velocidade de hemossedimentação 


\section{LISTA DE SÍMBOLOS}

$\begin{array}{ll}\% & \text { porcentagem } \\ < & \text { menor } \\ > & \text { maior } \\ \pm & \text { mais ou menos } \\ \mathrm{X} & \text { vezes } \\ { }^{\circ} \mathrm{C} & \text { graus Celsius } \\ { }^{\circledR} & \text { marca registrada }\end{array}$

(+) cruzes 
1 INTRODUÇÃO

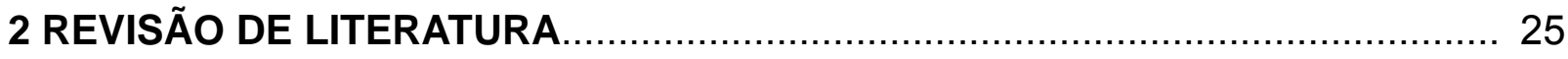

2.1 IMPACTO DE DOENÇAS NA CONSERVAÇÃO DE GRANDES CARNÍVOROS 25

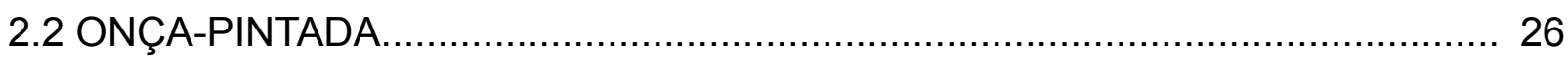

2.2.1 Ecologia

2.2.2 Hemograma e perfil bioquímico....................................................... 27

2.2.3 Enfermidades e patógenos relatados para a espécie............................... 28

2.3 PATÓGENOS VEICULADOS POR CARRAPATOS ...................................... 31

2.3.1 Gênero Rickettsia..................................................................... 31

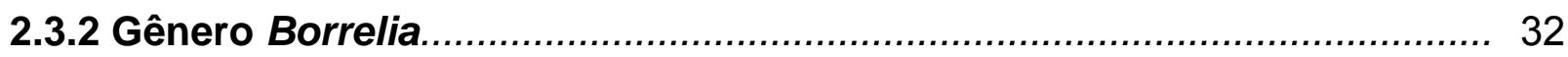

2.3.3 Gênero Coxiella

2.3.4 Família Anaplasmataceae ................................................................. 34

2.3.5 Gênero Babesia

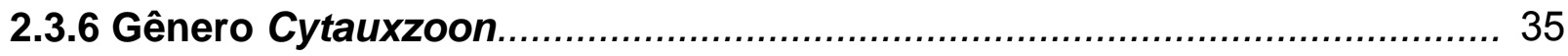

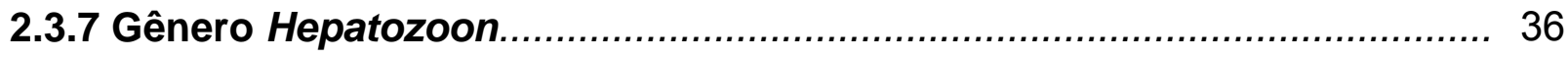

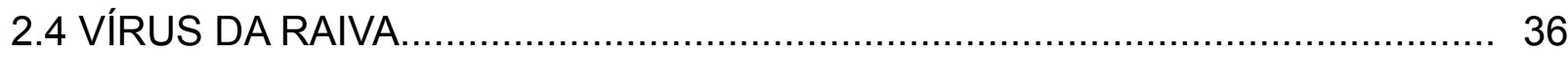

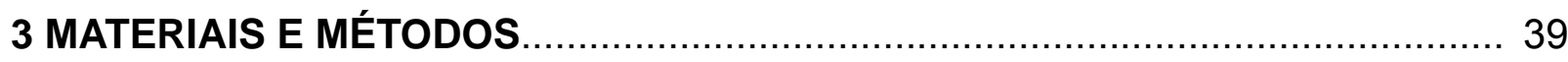

3.1 ÁREA DE ESTUDO E CONTEXTUALIZAÇÃO DO PROJETO............................ 39

3.2 CAPTURA, INSPEÇÃO E EXAME CLÍNICO................................................ 40

3.3 COLHEITA, ARMAZENAMENTO E TRANSPORTE DE AMOSTRAS............... 40

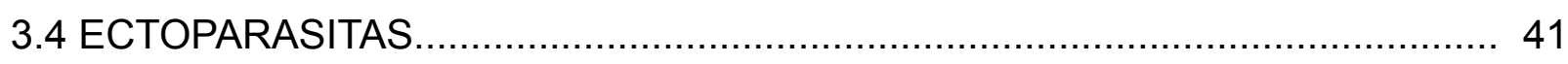

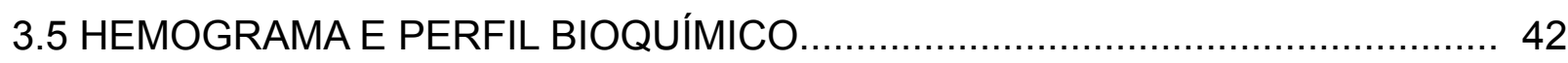

3.6 BUSCA POR HEMOPARASITAS EM LÂMINAS DE ESFREGAÇO................... 43

3.7 TESTES SOROLÓGICOS....................................................................... 43

3.7.1 Reação de imunofluorescência indireta para Rickettsia spp..................... 43

3.7.2 Reação de imunofluorescência indireta para Ehrlichia canis.................... 44

3.7.3 Microteste de Inibição de Fluorescência Simplificado para vírus rábico.. 45

3.8 REAÇÃO EM CADEIA PELA POLIMERASE (PCR).................................. 46

3.8.1 Extração de DNA dos carrapatos (larvas, ninfas e adultos).................... 46

3.8.2 Extração de DNA de coágulos sanguíneos.............................................. 47

3.8.3 PCR para Rickettsia spp............................................................... 47

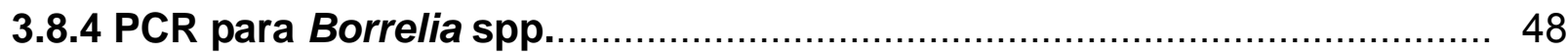




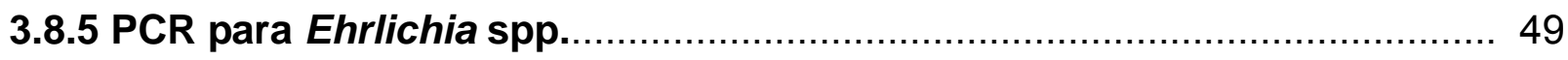

3.8.6 PCR para família Anaplasmataceae........................................................ 50

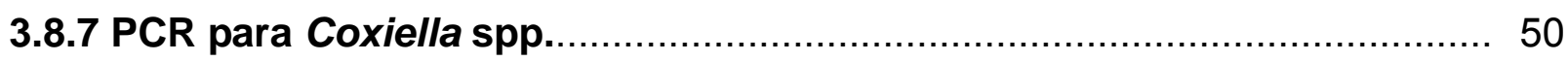

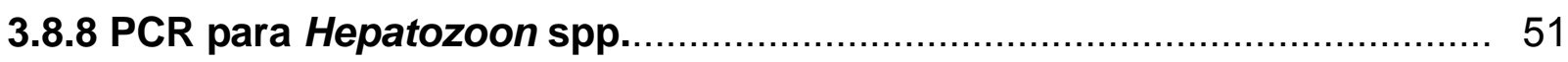

3.8.9 PCR para Babesia spp................................................................ 52

3.8.10 Eletroforese de DNA em gel de agarose ....................................... 53

3.8.11 Reação de sequenciamento genético e análise dos produtos................ 53

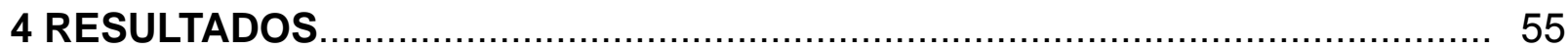

4.1 CAPTURA, INSPEÇÃO E EXAME CLÍNICO............................................. 55

4.1.1 Dados gerais das 10 onças-pintadas capturadas.................................... 55

4.1.2 Inspeção e exame clínico ..................................................................... 56

4.2 HEMOGRAMA E PERFIL BIOQUÍMICO....................................................... 57

4.2.1 Hemograma

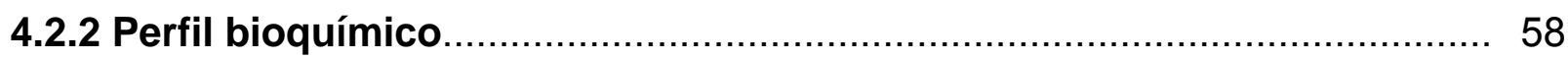

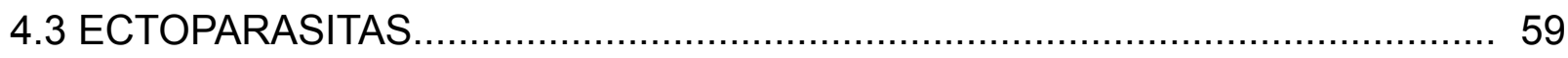

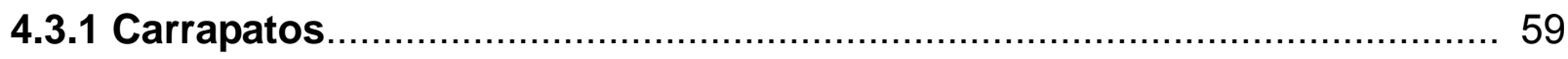

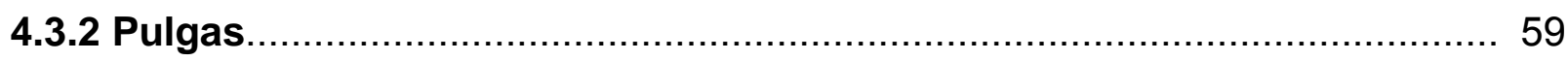

4.4 PATÓGENOS VEICULADOS POR ARTRÓPODES........................................ 59

4.4.1 Busca por hemoparasitas em esfregaço sanguíneo................................. 60

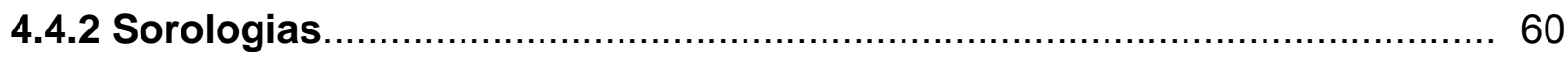

4.4.3 Testes pela reação em cadeia pela polimerase ...................................... 61

4.4.3.1 Resultados obtidos nas amostras de sangue das onças.......................... 61

4.4.3.2 Resultados obtidos nas amostras provenientes dos carrapatos coletados

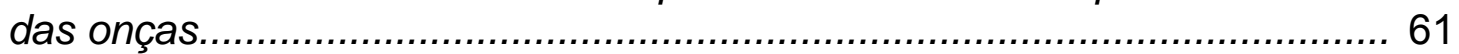

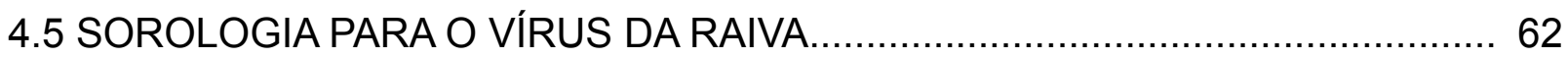

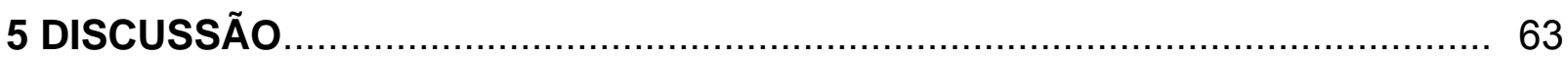

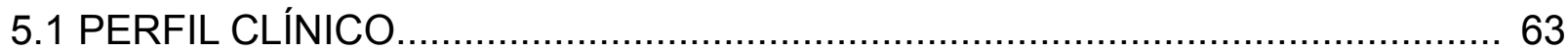

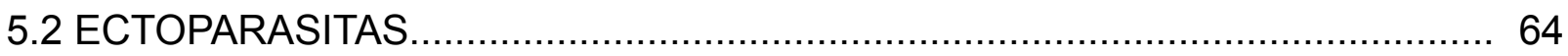

5.3 PATÓGENOS VEICULADOS POR ARTRÓPODES........................................ 64

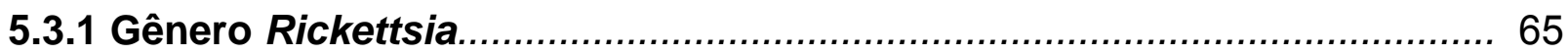

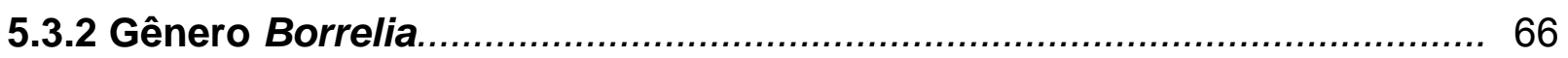

5.3.3 Gênero Coxiella

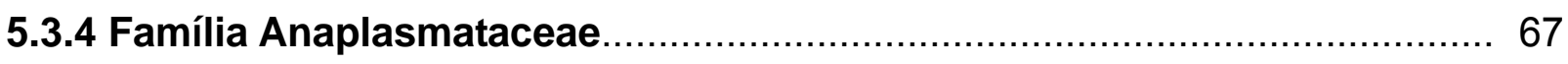

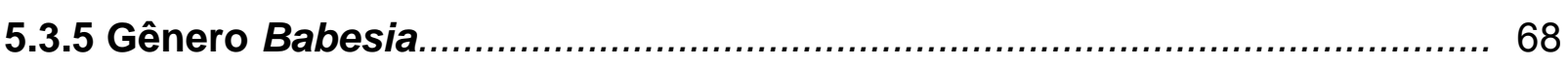

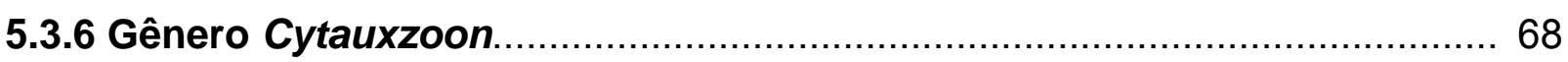




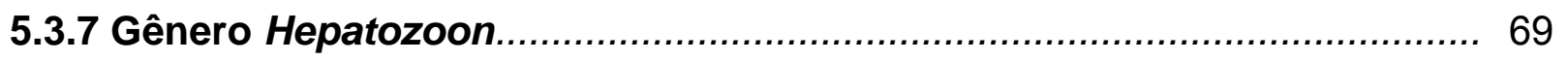

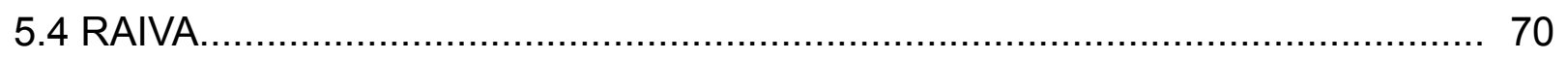

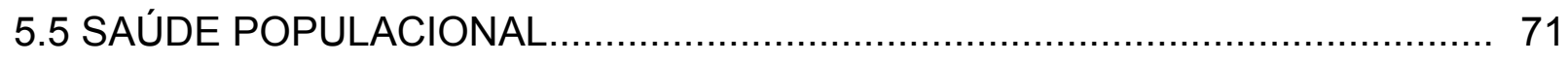

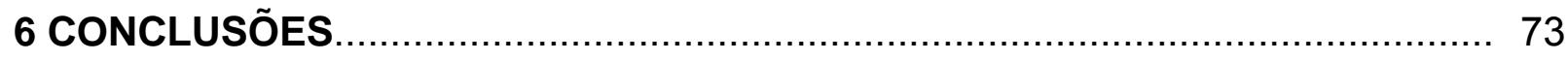

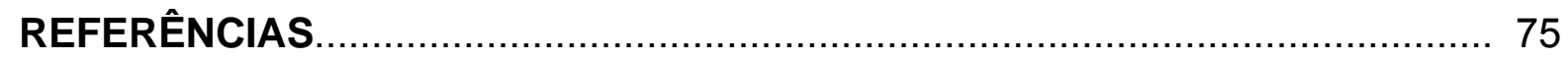

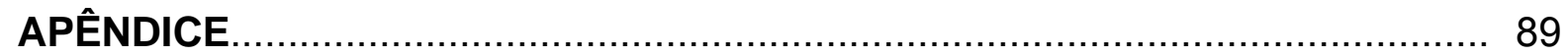




\section{INTRODUÇÃO}

Muitas espécies de grandes carnívoros, apesar de sua vital importância à estabilidade e integridade da maioria dos ecossistemas (MACDONALD; KAYS, 2005), estão seriamente ameaçadas de extinção por restrição de seus territórios, destruição de seus habitats e superexploração destes predadores e/ou suas presas (MURRAY et al., 1999). Entre os riscos enfrentados por estes animais de topo de cadeia alimentar estão as doenças infecciosas, com comprovados efeitos na conservação de algumas espécies (DASZAK; CUNNINGHAM; HYATT, 2000; FUNK et al., 2001).

Além de sua importância ecológica, carnívoros podem ser boas espécies sentinelas para uma grande diversidade de patógenos de importância em saúde pública e animal. A cada presa consumida, o predador tem maiores chances de ter contato com os agentes infecciosos presentes nas populações de presas, de forma que patógenos com baixa prevalência nas espécies de presas possam ter uma maior ocorrência nas espécies predadoras (CLEAVELAND et al., 2006). O uso destes animais como ferramentas para estudos de doenças como a raiva e doenças emergentes, como as transmitidas por vetores, tem sido empregado no mapeamento de áreas de risco para infecção humana e de animais domésticos, além de possibilitar a detecção de patógenos que possam ter importância na conservação dos próprios carnívoros e de outras espécies silvestres (AGUIRRE, 2009).

No mundo, uma das principais causas da emergência de doenças infecciosas é o contato de seres humanos com a vida silvestre, principalmente através da invasão e modificação humana dos habitats naturais (CUNNINGHAM, 2005). Entre os efeitos antrópicos estão as alterações climáticas e ambientais, que provavelmente tiveram grande influência nas epidemias de cinomose em leões africanos em 1994 e 2001, recentemente atribuídas a uma co-infecção do vírus causador desta doença e uma alta carga de Babesia spp. resultante de uma intensa infestação por carrapatos (MUNSON et al., 2008). Outro exemplo resultante da ação humana é a transmissão de doenças de animais domésticos para silvestres, como os surtos de raiva ocorridos em algumas espécies de canídeos africanos (SILERO-ZUBIRI; KING; MACDONALD, 1996; WILLIAMS et al., 2002).

A onça-pintada (Panthera onca), maior felídeo das Américas, é considerada uma 
espécie de grande importância à conservação dos habitats onde ocorre (SEYMOUR, 1989; MILLER; RABINOWITZ, 2002). A espécie é ameaçada de extinção em todo o seu território (CITES, 1975; IUCN, 2002; BRASIL, 2003) e as principais ameaças conhecidas são a destruição e fragmentação dos habitats e a caça em retaliação à predação de animais domésticos (FARREL; ROMAN; SUNQUIST, 2000). Até o momento não existem relatos de morbidade e mortalidade causadas por agentes infecciosos afetando populações desta espécie em vida livre. Porém, assim como para outros grandes carnívoros, o fato dos animais raramente serem encontrados e recuperados quando doentes ou logo após sua morte dificulta a avaliação da importância das doenças na dinâmica populacional (MURRAY et al., 1999).

O presente projeto teve como objetivo avaliar o perfil sanitário de uma população de onças-pintadas no Pantanal (Corumbá-MS), com especial ênfase em detectar a presença e/ou contato destes animais com o vírus rábico e bactérias e protozoários veiculados por carrapatos. 


\section{REVISÃO DE LITERATURA}

Este item consiste em uma breve revisão sobre a importância de doenças à conservação de grandes carnívoros, em dados relevantes sobre a biologia e saúde da onça-pintada, e informações sobre a epidemiologia e importância dos patógenos pesquisados neste projeto.

\subsection{IMPACTO DE DOENÇAS NA CONSERVAÇÃO DE GRANDES CARNÍVOROS}

Por ocuparem o topo da cadeia alimentar, os grandes carnívoros (peso máximo de adultos $>20 \mathrm{Kg}$, FULLER, 1985) são de vital importância à estabilidade e integridade da maioria dos ecossistemas (MACDONALD; KAYS, 2005). Porém estes animais sofrem pressões múltiplas pela degradação de habitats, caça, comércio ilegal e transmissão de doenças de animais domésticos (DASZAK; CUNNINGHAM; HYATT, 2000).

Os mamíferos da ordem Carnivora são suscetíveis a uma grande variedade de microparasitas debilitantes ou letais, muitos dos quais são transmitidos por espécies domésticas (MURRAY et al., 1999) e cujos efeitos podem ser potencializados em populações já ameaçadas devido a fatores como malnutrição, estresse ou baixa variabilidade genética (O’BRIEN et al., 1985; ULLREY, 1993; LLOYD, 1995).

Os recentes declínios em algumas populações de vida livre são um demonstrativo deste potencial devastador de doenças infecciosas na conservação destes animais (MURRAY, 1999; FUNK et al., 2001). Alguns exemplos são:

- A extinção dos cachorros selvagens africanos (Lycaon pictus) no Serengueti (Tanzania) entre 1970 e 1991, atribuída a surtos recorrentes de cinomose e raiva procedentes de cães domésticos (CREEL et al., 1997).

- A perda de cerca de $70 \%$ de uma população de lobos da Etiópia (Canis simensis) entre 1988 e 1992, com dois diagnósticos confirmados para raiva (SILLERO-ZUBIRI; KING; MACDONALD, 1996).

- A alta mortalidade de leões africanos (Panthera leo) no Serengueti e em Ngorongo Crater (Tanzânia) em 1994 e 2001, a princípio atribuída a 
epidemias de cinomose (ROELKE-PARKER et al., 1996; KISSUI; PACKER, 2004). Porém, através de um recente estudo retrospectivo, descobriu-se que a espécie havia tido contato outras vezes com o vírus causador desta doença sem a mesma letalidade, e que especialmente nos dois períodos em que muitos animais vieram a óbito, os leões apresentavam uma alta carga de Babesia spp. Este patógeno, comumente encontrado em búfalos nestas áreas, provavelmente teve sua transmissão facilitada por um aumento significativo das populações de carrapatos, resultante de alterações climáticas e influências antrópicas no ambiente (MUNSON et al., 2008).

\subsection{ONÇA-PINTADA}

A onça-pintada (Panthera onca) é o maior felídeo das Américas e, por ser um predador de topo de cadeia alimentar, é considerada uma espécie de grande importância à conservação dos habitats onde ocorre (SEYMOUR, 1989; MILLER; RABINOWITZ, 2002). A espécie é ameaçada de extinção em todo o seu território (CITES, 1975; IUCN, 2002; BRASIL, 2003) e as principais ameaças conhecidas são a destruição e fragmentação dos habitats e a caça em retaliação à predação de animais domésticos (FARREL; ROMAN; SUNQUIST, 2000).

\subsubsection{Ecologia}

A Panthera onca é um mamífero da ordem Carnivora, com ampla distribuição ao longo das Américas, sendo encontrada geralmente em áreas com considerável cobertura vegetal, suprimento de água e alimento (SEYMOUR, 1989).

As principais espécies de presa consumidas pela onça-pintada no Pantanal são capivara (Hydrochaeris hydrochaeris), gado (Bos taurus), jacaré (Caiman yacare), cervo do pantanal (Blastocerus dichotomus), veado mateiro (Mazama americana), queixada (Tayassu tajacu) e quatis (Nasua nasua) (AZEVEDO; MURRAY, 2007).

A onça-pintada apresenta hábito solitário, com exceção ao período em que as mães 
estão acompanhadas de filhotes e durante o acasalamento. No Pantanal do Mato Grosso do Sul, onças-pintadas têm áreas de vida extensas, com valor médio estimado de $49 \pm 36,02 \mathrm{~km}^{2}$, com pouca sobreposição de área entre indivíduos (AZEVEDO; MURRAY, 2007).

O período de gestação varia de 91 a 111 dias, sendo em média de 101 dias (HEMMER, $1979^{1}$ apud SEYMOUR 1989), e nascem de um a quatro filhotes, sendo mais comum nascerem dois (CANEVARI, $1983^{2}$ apud SEYMOUR 1989). Os filhotes permanecem com a mãe por um período de 1,5 a 2 dois anos até dispersarem para estabelecer seus próprios territórios (MONDOLFI; HOOGESTEIJN, 1986). A maturidade sexual é atingida entre 2 a 3 anos nas fêmeas (HEMMER, 1979 apud SEYMOUR 1989) e de 3 a 4 anos nos machos (MONDOLFI; HOOGESTEIJN, 1986).

\subsubsection{Hemograma e perfil bioquímico}

As informações acerca do perfil hematológico de onças-pintadas disponíveis na literatura científica são exclusivamente provenientes de animais mantidos em cativeiro, e os parâmetros analisados e resultados obtidos estão descritos na tabela abaixo (Tabela 2.1).

Tabela 2.1 - Parâmetros hematológicos de 18 onças-pintadas adultas e clinicamente saudáveis, mantidas em cativeiro pela Sociedade Zoológica de Londres (adaptado de: HAWKEY; HART, 1986). (continua)

\begin{tabular}{ll}
\hline Parâmetro & Média / Desvio Padrão (Intervalo) \\
\hline Hemoglobina $(\mathrm{g} / \mathrm{dl})$ & $12,8 \pm 1,0(11,0-15,0)$ \\
Glóbulos vermelhos $\left(1.000 / \mathrm{mm}^{3}\right)$ & $7.400,0 \pm 400,0(6.300,0-8.300,0)$ \\
hematócrito (litro/litro) & $0,38 \pm 0,04(0,33-0,48)$ \\
VCM (fl) & $49 \pm 5(42-62)$ \\
HCM (pg) & $16,9 \pm 1,5(15,5-20,7)$ \\
CHCM (g/dl) & $34.1 \pm 1,4(31,7-36,7)$ \\
Reticulócitos (\%) & $(0,0-0,6)$ \\
Glóbulos brancos $\left(/ \mathrm{mm}^{3}\right)$ & $9.300,0 \pm 2.200,0(4.200,0-12.400,0)$ \\
Neutrófilos $(\%)$ & $78 \pm 8$
\end{tabular}

${ }^{1}$ HEMMER, H. Gestation period and postnatal development in Felids. Carnivore, 2(2):90- 100. 1979.

${ }^{2}$ CANEVARI, M. El yaguareté. Buenos Aires: Centro Editor de America Latina, 1983. 32p. (Fauna Argentina, 21) 
Tabela 2.1 - Parâmetros hematológicos de 18 onças-pintadas adultas e clinicamente saudáveis, mantidas em cativeiro pela Sociedade Zoológica de Londres (adaptado de: HAWKEY; HART, 1986). (conclusão)

\begin{tabular}{ll}
\hline Parâmetro & Média / Desvio Padrão (Intervalo) \\
\hline Neutrófilos $(\%)$ & $78 \pm 8$ \\
Neutrófilos $\left(/ \mathrm{mm}^{3}\right)$ & $7.200,0 \pm 2.000,0(3.400,0-10.600,0)$ \\
Linfócitos $(\%)$ & $18 \pm 8$ \\
Linfócitos $\left(/ \mathrm{mm}^{3}\right)$ & $1.800,0 \pm 900,0(800-3.700,0)$ \\
Monócitos $(\%)$ & $(0-3)$ \\
Monócitos $\left(/ \mathrm{mm}^{3}\right)$ & $100,0 \pm 100,0(0,0-300,0)$ \\
Eosinófilos $(\%)$ & $(0-5)$ \\
Eosinófilos $\left(/ \mathrm{mm}^{3}\right)$ & $200,0 \pm 100,0(0,0-500,0)$ \\
Basófilos $(\%)$ & $(0-1)$ \\
Basófilos $\left(/ \mathrm{mm}^{3}\right)$ & $(0,0-100,0)$ \\
Plaquetas $\left(/ \mathrm{mm}^{3}\right)$ & $217.000,0 \pm 51.000,0(109.000,0-306.000,0)$ \\
Fibrinogênio $(\mathrm{d} / \mathrm{l})$ & $2,0 \pm 0,3(1,4-2,4)$ \\
VHS (mm em 1hora) & $18 \pm 17(0-58)$
\end{tabular}

VCM - Volume corpuscular médio

HCM - Hemoglobina corpuscular média

CHCM - Concentração de hemoglobina corpuscular média

VHS - velocidade de hemossedimentação

\subsubsection{Enfermidades e patógenos relatados para a espécie}

Na literatura científica existe apenas uma publicação sobre as principais causas de morbidade e mortalidade de onças-pintadas, e refere-se apenas a dados de cativeiro (HOPE; DEEM, 2006). As causas de mortalidade mais relevantes são aborto e morte neonatal, doenças reprodutivas e doenças musculoesqueléticas ou neuromusculares. As principais doenças relatadas em animais jovens e adultos são gastrintestinais (causadas por bactérias e endoparasitas), tegumentares (principalmente lesões em coxins e feridas em pele causadas por outra onça), neurológicas (automutilação) e dentais (fraturas, cálculos, doenças periodontais). Em animais idosos, além destas ocorrências destacam-se também doenças hepáticas, renais, hematológicas, neuromusculares e musculoesqueléticas, e doenças do aparelho reprodutivo nas fêmeas.

Até o momento não existem relatos das principais causas de mortalidade e 
morbidade afetando populações desta espécie em vida livre. Os principais agentes infecciosos já relatados para esta espécie, a evidência de exposição, o ambiente em que o(s) animal(is) eram mantidos e os autores da publicação são (Quadro 2.1):

Quadro 2.1 - Agentes infecciosos com ocorrência relatada em onças-pintadas. (continua)

\begin{tabular}{|c|c|c|c|c|}
\hline Agente & $\begin{array}{l}\text { Evidência de } \\
\text { exposição }\end{array}$ & Ambiente & Local & Referência \\
\hline \multicolumn{5}{|l|}{ Ectoparasitas } \\
\hline $\begin{array}{l}\text { Amblyomma } \\
\text { brasiliense }\end{array}$ & 1 & V & SP - Brasil & LABRUNA et al., 2005 \\
\hline A. cajenense & $1 / 1$ & $\mathrm{~V} / \mathrm{V}$ & $\begin{array}{l}\text { GO, MG, MS, MT - } \\
\text { Brasil / Paraguai }\end{array}$ & $\begin{array}{l}\text { LABRUNA et al., } 2005 \text { / } \\
\text { DURDEN et al., } 2006\end{array}$ \\
\hline A. coelebs & 1 & V & SP - Brasil & LABRUNA et al., 2005 \\
\hline A. oblongoguttatum & 1 & $\mathrm{~V}$ & RO - Brasil & LABRUNA et al., 2005 \\
\hline A. ovale & 1 & $\mathrm{~V}$ & $\begin{array}{l}\text { DF, MG, MS, PA, RO, } \\
\text { SP - Brasil }\end{array}$ & LABRUNA et al., 2005 \\
\hline A. parvum & $1 / 1$ & $\mathrm{~V} / \mathrm{V}$ & $\begin{array}{l}\text { DF, GO, SP - Brasil / } \\
\text { Paraguai }\end{array}$ & $\begin{array}{l}\text { LABRUNA et al., } 2005 \text { / } \\
\text { DURDEN et al., } 2006\end{array}$ \\
\hline A. tigrinum & $1 / 1$ & $\mathrm{~V} / \mathrm{V}$ & $\begin{array}{l}\text { GO, MG - Brasil / } \\
\text { Paraguai }\end{array}$ & $\begin{array}{l}\text { LABRUNA et al., } 2005 \text { / } \\
\text { DURDEN et al., } 2006\end{array}$ \\
\hline A. triste & $1 / 1$ & $\mathrm{~V} / \mathrm{V}$ & $\begin{array}{l}\text { GO, MS, SP - Brasil / } \\
\text { Paraguai }\end{array}$ & $\begin{array}{l}\text { LABRUNA et al., } 2005 \text { / } \\
\text { DURDEN et al., } 2006\end{array}$ \\
\hline Dermacentor nitens & 1 & $\mathrm{~V}$ & SP - Brasil & LABRUNA et al., 2005 \\
\hline Boophilus microplus & 1 & V & GO, MS, SP - Brasil & LABRUNA et al., 2005 \\
\hline Pulex simulans & 1 & $\mathrm{~V}$ & Paraguai & DURDEN et al., 2006 \\
\hline $\begin{array}{l}\text { Cochliomya } \\
\text { homnivorax }\end{array}$ & 1 & $\mathrm{~V}$ & Guiana & RAWLINS et al. 1983 \\
\hline \multicolumn{5}{|l|}{ Endoparasitas } \\
\hline Paragonimus sp. & 1 & V & Belize & PATTON et al., 1986 \\
\hline Taeniidae & 1 & V & Belize & PATTON et al., 1986 \\
\hline Strongylida & 1 & V & Belize & PATTON et al., 1986 \\
\hline Toxocara cati & 1 & V & Belize & PATTON et al., 1986 \\
\hline Toxascaris sp. & 1 & V & Belize & PATTON et al., 1986 \\
\hline Capillaria sp. & 1 & V & Belize & PATTON et al., 1986 \\
\hline Spiruridae & 1 & $\mathrm{~V}$ & Belize & PATTON et al., 1986 \\
\hline $\begin{array}{l}\text { Oncicola sp. } \\
\text { Protozoários }\end{array}$ & 1 & $\mathrm{~V}$ & Belize & PATTON et al., 1986 \\
\hline $\begin{array}{l}\text { Hammondia } \\
\text { pardalis }\end{array}$ & 1 & $\mathrm{~V}$ & Belize & PATTON et al., 1986 \\
\hline Isospora sp. & 1 & V & Belize & PATTON et al., 1986 \\
\hline Toxoplasma gondii & S & C & Brasil & RAMOS-SILVA et al., 2007 \\
\hline
\end{tabular}


Quadro 2.1 - Agentes infecciosos com ocorrência relatada em onças-pintadas. (conclusão)

\begin{tabular}{|c|c|c|c|c|}
\hline Agente & $\begin{array}{l}\text { Evidência de } \\
\text { exposição }\end{array}$ & Ambiente & Local & Referência \\
\hline Cytauxzoon sp. & $G$ & C & DF - Brasil & ANDRÉ et al., 2009 \\
\hline Hepatozoon canis & G & C & Venezuela & $\begin{array}{l}\text { CRIADO-FORNELIO et al., } \\
2009\end{array}$ \\
\hline Babesia canis & $S$ & C & DF, SP - Brasil & ANDRÉ, 2008 \\
\hline \multicolumn{5}{|l|}{ Fungos } \\
\hline Pythium insidiosum & SIGML & C & América Central & $\begin{array}{l}\text { CAMUS; GROOTERS; } \\
\text { AQUILAR, } 2004\end{array}$ \\
\hline \multicolumn{5}{|l|}{ Bactérias } \\
\hline Leptospira spp. & $S / S$ & $\mathrm{C} / \mathrm{V}$ & $\begin{array}{l}\text { Sudeste - Brasil / SP - } \\
\text { Brasil }\end{array}$ & $\begin{array}{l}\text { GUERRA-NETO, } 2006 \text { / } \\
\text { NAVA ,2008 }\end{array}$ \\
\hline Brucella sp. & $S$ & V & SP - Brasil & NAVA, 2008 \\
\hline Bartonella henselae & $S / G$ & $\mathrm{C} / \mathrm{C}^{*}$ & EUA / SP - Brasil & $\begin{array}{l}\text { YAMAMOTO et al., } 1998 \text { / } \\
\text { CATÃO-DIAS et al., } 2008\end{array}$ \\
\hline $\begin{array}{l}\text { Mycoplasma } \\
\text { haemofelis }\end{array}$ & $I^{* *}$ & C & MG - Brasil & RIVETTI-JÚNIOR, 2006 \\
\hline Ehrlichia canis & SG & C & SP - Brasil & ANDRÉ, 2008 \\
\hline Borrelia burgdorferi & $S$ & C & Alemanha & $\begin{array}{l}\text { STOEBEL; } \\
\text { SCHOENBERG; } \\
\text { STREICH, } 2003\end{array}$ \\
\hline \multicolumn{5}{|l|}{ Vírus } \\
\hline $\begin{array}{l}\text { Coronavírus felino } \\
\text { (FCoV) }\end{array}$ & $S G / S$ & $\mathrm{C} / \mathrm{C}$ & EUA / MT - Brasil & $\begin{array}{l}\text { KENNEDY et al., } 2002 \text { / } \\
\text { SCHIMITT et al., } 2003\end{array}$ \\
\hline $\begin{array}{l}\text { Vírus da cinomose } \\
\text { canina (CDV) }\end{array}$ & LS / S & $\mathrm{C} / \mathrm{V}$ & EUA / SP, MS - Brasil & $\begin{array}{l}\text { APPEL et al., } 1994 \text { / NAVA } \\
\text { et al., } 2008\end{array}$ \\
\hline $\begin{array}{l}\text { Vírus da } \\
\text { imunodeficiência } \\
\text { felina (FIV) }\end{array}$ & $S$ & C & MT - Brasil & SCHIMITT et al., 2003 \\
\hline $\begin{array}{l}\text { Vírus da leucemia } \\
\text { felina (FeLV) }\end{array}$ & G & C & MG - Brasil & RIVETTI-JÚNIOR, 2006 \\
\hline $\begin{array}{l}\text { Vírus do Oeste do } \\
\text { Nilo (WNV) }\end{array}$ & $S$ & C & México & FARFAN-ALE et al., 2006 \\
\hline $\begin{array}{l}\text { Herpesvírus felino } \\
\text { (FHV 1) }\end{array}$ & $S$ & C & Brasil & BATISTA et al., 2005 \\
\hline
\end{tabular}

* animal procedente do Pantanal, há apenas 1 semana em cativeiro

** identificação em lâmina de esfregaço sanguíneo

S - Positivo em teste sorológico

I - Identificação do parasita / isolamento do agente

G - Positivo em teste genético (PCR, RT-PCR)

$\mathrm{M}$ - Relato de morbidade

$\mathrm{L}$ - Relato de mortalidade

C - cativeiro

$\mathrm{V}$ - vida livre 


\subsection{PATÓGENOS VEICULADOS POR CARRAPATOS}

Doenças transmitidas por artrópodes têm notória importância para a saúde humana e saúde animal em diversos países. O aparecimento de novas enfermidades e a ressurgência de doenças transmitidas por vetores, algumas vezes sob a forma de epidemias, são atribuídas principalmente a alterações ecológicas que aumentaram as densidades das populações de vetores. Sem esquecer entretanto que o desenvolvimento de melhores métodos para diagnóstico também favorecem para que doenças sejam consideradas emergentes (GRATZ, 1999).

No mundo, carrapatos são considerados o segundo principal vetor para doenças infecciosas humanas, ficando atrás apenas dos mosquitos. Desde 1980 mais de 15 novos patógenos transmitidos por carrapatos foram descobertos (PAROLA; RAOULT, 2001).

No Brasil, dados preliminares da Secretaria de Vigilância em Saúde demonstram as rickettsioses como doenças emergentes, com importante aumento no número de casos e mortes humanas registrados nos últimos quinze anos (BRASIL, 2008a), porém ainda são deficientes os dados sobre a ocorrência, distribuição, principais vetores e eventuais morbidades e mortalidades nas espécies animais envolvidas na epidemiologia destas e outras doenças transmitidas por carrapatos no país.

\subsubsection{Gênero Rickettsia}

O gênero Rickettsia faz parte da família Rickettsiaceae e é composto por bactérias intracelulares obrigatórias, sendo dividas em dois grupos (RAOULT; ROUX, 1997):

- Grupo do Tifo (GT), composto pelas espécies Rickettsia prowazekii (transmitida por piolhos) e Rickettsia typhi (transmitida por pulgas);

- Grupo da Febre Maculosa (GFM), composto por mais de 23 espécies, das quais pelo menos 12 capazes de infectar o ser humano (Rickettsia rickettsii, R. conorii, R. africae, R. parkeri, R. australis, R. honei, R. sibirica, R. japonica, $R$. massiliae, $R$. aeschlimannii - transmitidas por carrapatos -, R. akari e $R$. felis - transmitidas por pulgas). 
No Brasil houve mais de 700 casos humanos de rickettsioses, 186 letais, nos últimos 20 anos. A grande maioria destes casos ocorreu na região sudeste, com alguns casos na região sul e um caso no Distrito Federal (BRASIL 2009a, b). As espécies relacionadas à doença humana no país (Febre Maculosa Brasileira) são a Rickettsia rickettsii, cujos sintomas são febre alta, cefaléia, mialgia e manchas na pele, com letalidade de 30\% (ANGERAMI et al., 2006); e Rickettsia parkeri, com sintomatologia mais branda e sem letalidade.

A R. rickettsii tem como principais vetores no país os carrapatos Amblyomma cajenense e Amblyomma aureolatum. A amplificação deste patógeno já foi comprovada em capivaras (Hydrochaeris hydrochaeris) e cães domésticos são considerados importantes sentinelas para a presença desta rickettsia (SOUZA, 2006; PINTER et al., 2008). Além desta, há evidências sorológicas de R. parkeri e $R$. bellii em capivaras (PACHECO et al., 2007).

\subsubsection{Gênero Borrelia}

As bactérias espiroquetas do gênero Borrelia que são patogênicas aos seres humanos estão divididas ecologicamente em dois grupos distintos, que são a Borrelia burgdorferi sensu lato, transmitida por carrapatos do gênero Ixodes e causadora da Doença de Lyme, e a espécie Borrelia lonestari, transmitida por carrapatos do gênero Amblyomma e causadora da Doença "STARI" (Southern TickAssociated Rash Illness), que é semelhante à primeira (STROMDAHL et al., 2003; STEERE; COBURN; GLICKSTEIN, 2004). Até o momento estas bactérias foram isoladas apenas na América do Norte, Europa e Ásia. Nos Estados Unidos e alguns países da Europa foram encontrados mamíferos da ordem Carnivora infectados por bactérias deste gênero (AGUIRRE et al., 2002).

A Doença de Lyme é a enfermidade humana transmitida por carrapatos mais comum no mundo e tem como principal sintoma o eritema migrans cutâneo, podendo apresentar também outros diversos sintomas multissistêmicos como a poliartrite (STEERE; COBURN; GLICKSTEIN, 2004).

No Brasil, a borreliose vem sendo diagnosticada desde 1992 porém sem sucesso no isolamento do agente e, devido às diferenças etiológicas, laboratoriais e clínicas 
quando comparada à Doença de Lyme, a doença no Brasil tem sido denominada como "Doença de Lyme-Símile" (YOSHINARI et al., 2003).

\subsubsection{Gênero Coxiella}

A Coxiella burnetti, uma bactéria gram-negativa intracelular obrigatória da família Legionellacea, é a causadora da Febre Q. A doença ocorre em praticamente todo o mundo, com exceção da Nova Zelândia, porém por raramente ser de notificação obrigatória, não tem sua incidência aferida na maioria dos países, incluindo o Brasil. Esta enfermidade pode ter alta prevalência em muitos países, mas provavelmente não é diagnosticada por não crescer nos meios de cultura rotineiramente utilizados para suspeitas de infecção bacteriana (MAURIN; RAOULT, 1999).

A maioria das infecções em humanos são assintomáticas ou apresentam sintomas inespecíficos semelhantes a um resfriado (DUPUIS et al., 1987). Nos casos sintomáticos agudos os dois principais achados clínicos são pneumonia atípica e hepatite, mas também podem ser afetados baço, medula óssea e trato genital feminino. As principais complicações no quadro clínico de pacientes com a doença são meningoencefalite, miocardite e/ou pericardite (MAURIN; RAOULT, 1999). Em infecções crônicas o principal sintoma é endocardite (RAOULT et al., 1990).

O público mais atingido por esta doença são pessoas que trabalham em contato com animais domésticos como gado, carneiro e, em proporções menores, cabras (MAURIN; RAOULT, 1999). A principal via de infeção para seres humanos é por aerossóis, principalmente por contato com fluídos expelidos durante o parto de animais infectados (MARRIE, 1990).

Esta bactéria tem diversas espécies como reservatórios, incluindo mamíferos domésticos e selvagens, aves e mais de 40 espécies de carrapatos. Nos animais é comum a infecção crônica, porém ela geralmente é assintomática (BALBUDIERI, 1959; MAURIN; RAOULT, 1999).

A transmissão por carrapatos, apesar de não ser de grande importância na epidemiologia deste patógeno em seres humanos, pode ter uma alta relevância para a infecção de diferentes espécies de vertebrados silvestres (BALBUDIERI, 1959).

Apesar de existirem dados soroepidemiológicos sobre a ocorrência da Febre $Q$ no 
Brasil, são raros os relatos da doença (SICILIANO et al., 2008). A primeira série de casos desta doença no país foi publicada em 2006, e se baseou em achados clínicos e sorológicos de 16 pacientes de Minas Gerais entre os anos de 2001 e 2004 (COSTA; BRIGATTE;GRECO, 2006).

\subsubsection{Família Anaplasmataceae}

A família Anaplasmataceae, constituída de bactérias intracelulares obrigatórias, engloba os agentes causadores da erliquiose e anaplasmose humanas incluindo Ehrlichia chaffeensis, E. canis, E. ewingii, Neorickettsia sennetsu e Anaplasma phagocytophilum. As principais manifestações clínicas e achados laboratoriais em pessoas doentes são febre alta, cefaléia, mialgia, mal-estar, frequente acometimento respiratório e/ou gastrintestinal, trombocitopenia, leucopenia e aumento de transaminases (LEPIDI et al., 2000; BAKKEN; DUMLER, 2006).

No Brasil, os primeiros casos suspeitos de erliquiose humana foram descritos no estado de Minas Gerais, o diagnóstico foi estabelecido através de sintomatologia clínica compatível e sorologia positiva para E. chaffeensis (CALIC et al., 2004), porém até o momento este patógeno não foi isolado a partir de amostras humanas. Uma das confirmações da presença deste patógeno no país foi através do sequenciamento genético obtido a partir de amostras de cervo do pantanal (Blastocerus dichotomus) da região do Rio Paraná (MACHADO et al., 2006).

A Ehrlichia canis é atualmente o patógeno transmitido por carrapatos mais importante para cães na América Latina, sendo o mais prevalente em cães no Brasil e causando a erliquiose monocítica canina (SAITO et al., 2008). Este patógeno já foi sequenciado a partir de amostra de onça-pintada em cativeiro no estado de São Paulo (ANDRÉ, 2008).

\subsubsection{Gênero Babesia}

Os hemoprotozoários do gênero Babesia, piroplasmas da família Babesiidae, são os 
causadores da babesiose, doença de distribuição mundial transmitida por carrapatos, e que infecta seres humanos, animais selvagens e domésticos, causando grandes prejuízos econômicos na criação de gado, por exemplo. Em humanos os principais sintomas relatados são febre, calafrios, mialgia e fadiga, com eventual anemia e esplenomegalia (YOSHINARI et al., 2003).

Apesar de haver relatos de pessoas com sorologia positiva para Babesia sp. no Brasil, o único caso com identificação do agente foi feito em lâmina de esfregaço sanguíneo de um paciente em Pernambuco (ALECRIM et al., 1983).

Parasitas deste gênero foram recentemente considerados parte fundamental para a alta mortalidade de leões nos surtos de cinomose que ocorreram na Tanzânia, uma vez que durante os surtos havia uma co-infecção pelo vírus da cinomose canina (CDV) e uma alta carga de Babesia sp (MUNSON et al., 2008). Em um estudo recente foram diagnosticadas onças-pintadas de cativeiro com sorologia positiva para Babesia canis no estado de São Paulo e no Distrito Federal, porém sem isolamento do agente (ANDRÉ, 2008).

\subsubsection{Gênero Cytauxzoon}

Os protozoários do gênero Cytauxzoon, piroplasmas da família Theileriidae, são os causadores da cytauxzoonose. A espécie mais conhecida deste gênero, Cytauxzoon felis, costuma causar uma doença de evolução aguda e com quase $100 \%$ de letalidade ao infectar gatos domésticos (Felis catus)(MEIER; MOORE, 2000).

Nos Estados Unidos acredita-se que linces (Lynx rufus), que apresentam altas prevalências para $C$. felis em algumas regiões, sejam importantes reservatórios deste patógeno, existindo apenas um caso de mortalidade de um animal de vida livre desta espécie por cytauxzoonose (NIETFELD; POLLOCK, 2002).

No Brasil, o primeiro relato de $C$. felis foi feito em dois leões que vieram a óbito com quadro clínico e achados histopatológicos compatíveis com cytauxzoonose (PEIXOTO et al., 2007).

Dois anos depois foi relatada a primeira detecção molecular de Cytauxzoon felis em onça-pintada e outros felinos silvestres de cativeiro, todos sem sintomas clínicos, sugerindo que estes animais possam ser reservatório deste parasita no país 
(ANDRÉ et al., 2009).

A patogenicidade de protozoários do gênero Cytauxzoon é desconhecida para seres humanos.

\subsubsection{Gênero Hepatozoon}

Os protozoários do gênero Hepatozoon, da família Haemogregarinidae, são descritos infectando praticamente todos os grupos de vertebrados terrestres e inúmeros invertebrados hematófagos (SMITH, 1996). A infecção do hospedeiro vertebrado se dá através da ingestão do invertebrado (BANETH et al., 1998).

Em cães domésticos (Canis familiaris) a infecção por Hepatozoon sp. pode ser muito debilitante (EWING; PANCIERA, 2003), porém gatos (Felis catus) não apresentam sintomas específicos (BANETH et al., 1998).

O primeiro relato deste patógeno em felinos silvestres brasileiros foi publicado em 2008, relatando a presença de Hepatozoon sp. em jaguatiricas (Leopardus pardalis) e gato do mato pequeno (Leopardus tigrinus) (METZGER et al., 2008). Recentemente foi publicado o primeiro relato da ocorrência de Hepatozoon canis em onça-pintada, sequenciado a partir de amostras de um animal de vida livre da Venezuela (CRIADO-FORNELIO et al., 2009). Nenhum destes felinos apresentava sintomas.

A patogenicidade de protozoários do gênero Hepatozoon é desconhecida para seres humanos.

\subsection{VÍRUS DA RAIVA}

A raiva, doença causada por vírus do gênero Lyssavirus (família Rhabdoviridae), é decorrente de uma infecção do sistema nervoso central, quase $100 \%$ letal, com alguns poucos casos de recuperação. No mundo a doença é caracterizada por grandes áreas epizoóticas com um ou poucos reservatórios, geralmente carnívoros ou quirópteros (WILLIAMS et al., 2002). 
Nos países da América do Sul a infecção de pessoas acontece principalmente através da mordida de cães domésticos raivosos (CHILDS, 2002). Porém, assim como vem acontecendo nos países da América do Norte, provavelmente também na América do Sul os países terão que, após eficiente controle da raiva em animais domésticos, passar a controlar esta doença em animais silvestres como forma de prevenir a infecção humana (BERNARDI et al., 2005). No Brasil entre 1990 e 2008, a raiva foi responsável pela morte de quase 600 pessoas (BRASIL, 2009c).

Além da importância em saúde pública, a raiva também pode ser de grande relevância em espécies de carnívoros ameaçadas de extinção, como ficou evidenciado nos surtos ocorridos em alguns canídeos africanos (GASCOYNE et al., 1993; SILERO-ZUBIRI; KING; MACDONALD, 1996; WILLIAMS et al., 2002).

Nas espécies de carnívoros silvestres brasileiros, há evidências de que o cachorro do mato (Cerdocyon thous) seja o principal reservatório deste grupo no Nordeste (CARNIELI et al., 2008). No Pantanal o contato com o vírus foi detectado em um cachorro-vinagre (Speothos venaticus), um canídeo silvestre ameaçado de extinção, e que apresentou alto título sorológico para este agente (JORGE, 2008). Não existe relato desta doença em onças-pintadas. 


\section{MATERIAIS E MÉTODOS}

Neste item são apresentados dados sobre a área onde foi realizado este estudo e os métodos utilizados para captura dos animais, colheita de amostras, análises laboratoriais e dos resultados obtidos.

\section{1 ÁREA DE ESTUDO E CONTEXTUALIZAÇÃO DO PROJETO}

Este estudo foi realizado no Pantanal, planície inundável com uma área aproximada de $140.000 \mathrm{~km}^{2}$ no Centro-Oeste brasileiro, próximo às fronteiras com a Bolívia e o Paraguai. Este bioma é caracterizado por um regime anual de inundação e estiagem, e é composto por um conjunto de rios, lagoas, brejos, pastagens, florestas alagáveis, matas de galeria e florestas não alagáveis (AZEVEDO; MURRAY, 2007). As capturas foram realizadas na fazenda São Bento e propriedades vizinhas, localizadas no município de Corumbá, região sudeste do Mato Grosso do Sul (SA69 495756 7844581). A pecuária, seguida do turismo, é a principal atividade econômica da região.

A fazenda tem área aproximada de 10.000 hectares, constituídos por extensas áreas de pasto nativo, pasto introduzido, capões de mata nativa e matas de galeria ao longo dos cursos dos rios Abobral e Miranda e dos inúmeros corixos presentes na fazenda.

Este estudo é um subprojeto do "Projeto Onça Pantaneira", pesquisa de pósdoutorado do Dr. Fernando Azevedo (Laboratório de Ecologia Animal - ESALQ/USP), o qual visa obter dados sobre área de vida, movimentação, reprodução e alimentação das onças-pintadas, com especial enfoque à predação de gado por estes felinos, buscando obter dados que subsidiem ações de manejo que minimizem os conflitos com os produtores de gado. 


\subsection{CAPTURA, INSPEÇÃO E EXAME CLÍNICO}

Entre março e agosto de 2008 foram capturadas 10 onças-pintadas (licença IBAMA $n^{0}$ 10608-1). Nos três primeiros meses houve um esforço de captura com armadilhas de ferro tipo caixa, checadas diariamente (AZEVEDO; MURRAY, 2007), porém sem sucesso. Depois foram utilizados cães treinados, os quais eram utilizados para localizar e acurralar a onça após a equipe encontrar um rastro fresco do animal. Quando perseguidas as onças na maioria das vezes subiram em árvores, facilitando o tiro com dardo anestésico.

A imobilização química foi feita com a associação de cloridrato de tiletamina e cloridrato de zolazepam (Zoletil100®) na dose de $10 \mathrm{mg} / \mathrm{Kg}$ (MORATO, 1997), através de seringas de alumínio de $3-5 \mathrm{ml}$ projetadas por pistola ou rifle de gás carbônico (Cap-Chur ${ }^{\circledR}$ ), e quando necessária suplementação foi utilizada 1/4 ou 1/2 da dose inicial. Cada animal teve sua anestesia acompanhada a cada 15 minutos por um médico veterinário, o qual aferiu temperatura, frequências cardíaca e respiratória, coloração de mucosas e outros parâmetros.

Após completa imobilização, cada animal foi submetido a inspeção e exame clínico de acordo com ficha clínica (Apêndice 1), com especial atenção a avaliação de fase reprodutiva, possíveis lesões, debilidades e idade relativa do animal, esta última estimada com base na coloração e condição da dentição. Por não ter sido possível acompanhar todas as capturas, dois biólogos foram treinados sobre como era avaliado cada item, de forma que pudessem auxiliar os outros dois veterinários que estiveram presentes em capturas.

Como parte de um estudo ecológico, as onças capturadas foram também medidas, pesadas e equipadas com colar provido de Sistema de Posicionamento Global (GPS), sendo possível obter dados de acompanhamento dos animais como morte e nascimento de filhotes.

\subsection{COLHEITA, ARMAZENAMENTO E TRANSPORTE DE AMOSTRAS}

Um dos primeiros procedimentos após constatar a boa resposta dos animais à 
imobilização química foi coletar amostras de sangue através de punção da veia cefálica ou safena lateral utilizando tubos a vácuo com ácido etilodiaminotetracético (EDTA) e tubos sem aditivos.

A separação das amostras foi feita com uso de centrífuga, no mesmo dia da captura, a $1.500 \mathrm{rpm}$ por 10 minutos. Depois amostras de sangue total, soro, coágulo, plasma, papa de leucócitos e papa de hemácias foram aliquotadas com uso de pipeta estéril descartável em criotubos de $2 \mathrm{ml}$, congeladas e armazenadas em galão de nitrogênio líquido.

Um tubo contendo sangue e EDTA e um criotubo com 1,0 ml de soro de cada animal foram armazenados em geladeira para serem encaminhados em até 24 horas ao Laboratório Carlos Chagas, na cidade de Corumbá para realização de hemograma e perfil bioquímico.

Após as 10 capturas, as amostras de soro e coágulo foram transportadas ao Laboratório de Doenças Parasitárias da FMVZ-USP, sendo mantidas em isopor com gelo reciclável (tempo total de deslocamento de 12 horas) e armazenadas em freezer ao chegar ao laboratório.

\subsection{ECTOPARASITAS}

Durante 3 minutos foi feita a coleta e contagem do número de carrapatos para possibilitar uma estimativa de carga parasitária, sendo estes - e outros ectoparasitas que fossem encontrados além deste tempo - armazenados em frascos com álcool $98 \%$.

Este material foi depois transportado ao Laboratório de Doenças Parasitárias da FMVZ/USP para identificação das espécies através de características morfológicas (LINARDI; GUIMARÃES, 2000; BARROS-BATESTI; ARZUA; BECHARA, 2006) e busca da presença de DNA de patógenos selecionados nos carrapatos. 


\subsection{HEMOGRAMA E PERFIL BIOQUÍMICO}

O hemograma e perfil bioquímico de cada animal foi realizado em até 24 horas após a captura no Laboratório Carlos Chagas na cidade de Corumbá - MS (laboratório humano).

O hemograma foi realizado utilizando o aparelho ABX micro 60 (Horiba ${ }^{\circledR}$ ), sendo os dados conferidos através de leitura de lâmina de esfregaço corada pelo método de May Grunwald Giemsa e analisada em microscópio Nikon Eclipse E200 (Nikon ®), sob objetiva de 100x. A lâmina de esfregaço era preferencialmente confeccionada ainda a campo. Os seguintes parâmetros foram avaliados: glóbulos vermelhos, hemoglobina, hematócrito, volume corpuscular médio (VCM), hemoglobina corpuscular média (HCM), concentração de hemoglobina corpuscular média (CHCM), plaquetas, glóbulos brancos, bastonetes, segmentados, eosinófilos, basófilos, linfócitos, monócitos, mielócitos e metamielócitos.

Para análise do perfil bioquímico foi utilizado um aparelho de automação para ELISA e bioquímica ChemWell (Awareness Technology $\AA$ - EUA), e foram avaliados os seguintes parâmetros, com as respectivas técnicas (Quadro 3.1):

Quadro 3.1 - Parâmetros utilizados neste estudo para análise do perfil bioquímico e respectivas técnicas. (continua)

\begin{tabular}{|l|l|}
\hline Parâmetro & Técnica utilizada \\
\hline Uréia & Enzimático \\
Creatinina & Lustosa-Basques \\
Fosfatase alcalina (FA) & Roy modificado \\
Aspartato aminotransferase (AST) & Reitman e Frankel \\
Alanina aminotransferase (ALT) & Reitman e Frankel \\
Gama glutamil transferase (GGT) & cinético \\
Bilirrubina total & Sims-Horn \\
Bilirrubina direta & Sims-Horn \\
Bilirrubina indireta & Sims-Horn \\
Creatinofosfoquinase (CPK) & enzimático \\
Colesterol total & enzimático-Trinder \\
Triglicerídeos & enzimático-Trinder \\
Colesterol HDL & enzimático \\
Ácido Úrico & enzimático \\
Proteínas totais & Biureto \\
\hline
\end{tabular}


Quadro 3.1 - Parâmetros utilizados neste estudo para análise do perfil bioquímico e respectivas técnicas. (conclusão)

\begin{tabular}{|l|l|}
\hline Albumina & Verde de bromocrezol \\
Globulinas & Biureto \\
Ferro sérico & Goodwin modificado \\
\hline
\end{tabular}

\subsection{BUSCA POR HEMOPARASITAS EM LÂMINAS DE ESFREGAÇO}

As lâminas de esfregaço sanguíneo utilizadas no hemograma e lâminas de esfregaço feitas com sangue periférico (capilar de ponta de orelha) foram coradas pelo método de May Grunwald Giemsa e analisadas em microscópio Nikon Eclipse E200 (Nikon $®)$, sob objetiva de 100x, para busca por hemoparasitas. Esta análise foi feita no mesmo laboratório onde foram realizados o hemograma e testes bioquímicos.

\subsection{TESTES SOROLÓGICOS}

Este item descreve os métodos utilizados para pesquisa da presença de anticorpos para Rickettsia spp., Ehlichia canis e vírus rábico no soro das onças-pintadas.

\subsubsection{Reação de imunofluorescência indireta para Rickettsia spp.}

Amostras de soro das 10 onças-pintadas foram testadas no Laboratório de Doenças Parasitárias da FMVZ-USP através da Reação de Imunofluorescência Indireta (RIFI) para detecção de anticorpos ( $\operatorname{lgG}$ ) para cada um das seguintes bactérias do gênero Rickettsia, utilizando lâminas confeccionadas no próprio laboratório a partir de células VERO infectadas com as respectivas cepas:

$R$. rickettsii CEPA Mogi (PINTER; LARBUNA, 2006)

R. parkeri CEPA At\#24 (SILVEIRA et al., 2007) 
R. bellii CEPA Mogi (PINTER; LABRUNA, 2006)

R. rhipicephali CEPA Hj\#5 (LABRUNA et al., 2007)

R. amblyommii CEPA Ac\#37 (LABRUNA et al., 2004)

$E$ também utilizando lâminas confeccionadas neste mesmo laboratório a partir de células de mosquito linhagem C6/36, infectadas com R. felis, CEPA Pedreira (HORTA et al., 2006).

Para triagem foi utilizada a diluição do soro em PBS pH 7,4 nas proporções 1:64 e, para amostras positivas, em diluição seriada até 1:1024. Amostras de gatos domésticos (Felis catus) conhecidas foram utilizadas como controle negativo e positivo para cada reação.

Para todas as lâminas foi utilizado o mesmo protocolo:

Cada lâmina foi imersa em cuba com PBS pH 7,4 por 10 minutos e seca em estufa por 30 minutos. Depois, adicionou-se $15 \mu$ da diluição de soro a cada pocinho, para então encubar a lâmina por 30 minutos em câmara úmida a $37^{\circ} \mathrm{C}$. Após isso, a lâmina foi imersa duas vezes por 10 minutos em cuba com Washing Buffer (PBS com triton 1\%) e novamente seca em estufa por 30 minutos. Foi então adicionado $15 \mu$ l a cada pocinho da diluição do conjugado, e a lâmina foi mais uma vez encubada em câmara úmida a $37^{\circ} \mathrm{C}$ por 30 minutos. Terminado este procedimento, a lâmina foi imersa duas vezes por 10 minutos em cuba com Washing Buffer misturado a aproximadamente $1 \mathrm{ml}$ de Azul de Evans $(2 \mathrm{mg} / \mathrm{ml})$ em câmara escura e posteriormente seca em temperatura ambiente em sala escura. Para leitura foi adicionada pequena quantidade de glicerina e uma lamínula e analisadas as lâminas em microscópio de imunofluorescência, com objetiva de 40x (Nikon®).

O conjugado utilizado foi o de gato doméstico (Felis catus) da marca Kirkegaard \& Perry Laboratories $®$ (Affinity Purified Antibody Flurescein Labeled, Goat anti-Cat IgG $(H+L)$ 0,5mg) na diluição 1:400.

\subsubsection{Reação de imunofluorescência indireta para Ehrlichia canis}

Amostras de soro das 10 onças-pintadas foram testadas no Laboratório de Doenças Parasitárias da FMVZ-USP através da Reação de Imunofluorescência Indireta (RIFI) para Ehrlichia canis, utilizando lâminas confeccionadas no próprio laboratório a partir 
de células de linhagem de origem canina canina DH82 infectadas com Ehrlichia canis CEPA São Paulo (AGUIAR; HAGIWARA; LABRUNA, 2008). Para triagem foi utilizada a diluição do soro em PBS pH 7,2 com $2 \%$ de soro de coelho na proporção 1:64 e, para amostras positivas, em diluição seriada até 1:1024.

As lâminas foram lavadas brevemente em água destilada e secas em temperatura ambiente. Foram então adicionados $15 \mu \mathrm{l}$ da diluição de soro a cada pocinho e as lâminas foram encubadas em câmara úmida a $37^{\circ} \mathrm{C}$ por 30 minutos. Depois as lâminas foram imersas suas vezes por 5 minutos em $\mathrm{PBS} \mathrm{pH} 7,2$, lavadas brevemente em água destilada e secas em temperatura ambiente. Após a secagem foi adicionado $15 \mu \mathrm{l}$ da diluição do conjugado a cada pocinho e as lâminas foram novamente encubadas em câmara úmida por 30 minutos. Terminado este procedimento, as lâminas foram imersas duas vezes por 5 minutos em cuba com PBS pH 7,2 misturado a aproximadamente $1 \mathrm{ml}$ de Azul de Evans (2mg/ml) em câmara escura, mais uma vez lavadas brevemente em água destilada e posteriormente secas em temperatura ambiente em sala escura.

Para leitura foi adicionada pequena quantidade de glicerina e uma lamínula e analisadas as lâminas em microscópio de imunofluorescência, objetiva de 40x (Nikon®).

O conjugado utilizado foi o de gato doméstico (Felis catus) da marca Kirkegaard \& Perry Laboratories (Affinity Purified Antibody Flurescein Labeled, Goat anti-Cat IgG $(H+L)$ 0,5mg) na diluição 1:400.

\subsubsection{Microteste de Inibição de Fluorescência Simplificado para vírus rábico}

Amostras de soro de todos os animais foram testadas no Laboratório de Sorologia do Instituto Pasteur de São Paulo, através de Microteste de Inibição de Fluorescência Simplificado - SFMIT (FAVORETTO et al., 1993), que confere a titulação final em Unidades Internacionais (UI).

Foram utilizados como soros padrão o soro padrão humano do Instituto Pasteur e soro padrão animal da OIE em 6 diluições (de 1:10 a 1:320), e foram feitas 12 diluições dos soros das onças (de 1:10 a 1:20480). Foram utilizados como controle positivo e negativo soros animais do Instituto Pasteur. 
Os lotes dos materiais utilizados foram: Meio de cultura MEM SFB lote IPMEM 05/09, Soro padrão humano IPSPH 02/08, Soro controle + animal IPCPA 01/09, Soro controle - animal IPCNA 01/08, Soro padrão animal OIE, Vírus PV lote 01/08 diluição 1:40, Célula linhagem BHK-21 passagem 77, Conjugado TOT IPTOT 2/08 diluição 1:70, ATV IPATV 01/09, Acetona IPACE 05/09, PBS IPPBS 6/09, Glicerina IPGLI 06/09.

\subsection{REAÇÃO EM CADEIA PELA POLIMERASE (PCR)}

Este item descreve os métodos utilizados para extração de DNA dos carrapatos coletados e de amostras de coágulos das onças, os métodos utilizados para amplificação de DNA de Rickettsia spp., Borrelia spp., Ehlichia spp., família Anaplasmataceae, Coxiella spp., Hepatozoon spp., Babesia spp., e os métodos para verificação da presença de amplímeros e, em casos positivos, de sequenciamento e análise dos produtos.

\subsubsection{Extração de DNA dos carrapatos (larvas, ninfas e adultos)}

Os carrapatos adultos foram individualizados e as ninfas de mesmo gênero coletadas de uma mesma onça, assim como as larvas, foram separadas em grupos de até 3 indivíduos para formação de "pool" para extração de DNA em microtubos de $1,5 \mathrm{ml}$, segundo protocolo adaptado de Chomczynski (1993). Fêmeas e indivíduos ingurgitados foram cortados preservando apenas o terço proximal para a extração.

Os carrapatos foram triturados com auxílio de agulha estéril e posteriormente a cada macerado foi adicionado $150 \mu$ l de tampão TE pH 8,0 (10mM TRIS Hcl; 1 mM EDTA) e $450 \mu \mathrm{l}$ de isotiocianato de guanidina, seguido de homogeinização e adição de $100 \mu \mathrm{l}$ de clorofórmio. Esta mistura era então centrifugada (12.000 g por 5 minutos) e a fase aquosa recuperada e transferida a um novo microtubo estéril, ao qual era adicionado $600 \mu l$ de isopropanol para então ser armazenado por um tempo mínimo de 2 horas em freezer $\left(-20^{\circ} \mathrm{C}\right)$. Após este período a solução foi novamente centrifugada (12.000 
$g$ a $4^{\circ} \mathrm{C}$ por 15 minutos), o sobrenadante descartado, e o sedimento ressuspenso em $800 \mu \mathrm{l}$ de etanol $70 \%$ para então ser mais uma vez centrifugado $\left(12.000 \mathrm{~g}\right.$ a $4^{\circ} \mathrm{C}$ por 15 minutos). O sobrenadante foi descartado e o sedimento final seco em temperatura ambiente por aproximadamente 1 hora e ressuspenso em $60 \mu$ de TE e colocado em termobloco a $56^{\circ} \mathrm{C}$ por 15 minutos para facilitar a dissolução do DNA. Esta solução de DNA final foi então armazenada em freezer $\left(-20^{\circ} \mathrm{C}\right)$ até seu uso para a PCR.

Cada processo de extração foi feito com no máximo 10 amostras e pelo menos um controle de extração, este último sendo testado em todas as reações em cadeia pela polimerase.

\subsubsection{Extração de DNA de coágulos sanguíneos}

A extração de DNA de amostras de coágulo sanguíneo das 10 onças-pintadas foi feita utilizando o DNeasy Tissue Kit (Qiagen $®)$, conforme recomendação do fabricante, e com dois controles de extração, os quais foram testados em todas as reações em cadeia pela polimerase (PCR).

\subsubsection{PCR para Rickettsia spp.}

Para busca de DNA de bactérias do gênero Rickettsia nas amostras de DNA extraídas das onças e dos carrapatos foram utilizados os oligonucleotídeos iniciadores (primers) 62 (5'-GCTTTACAAAATTCTAAAAACCATATA-3') e 464 (5'TGTCTATCAATTCACAACTTGCC-3') para amplificação de parte do gene gltA (LABRUNA et al., 2004).

A reação de amplificação foi feita em microtubos de $200 \mu$ l adicionando $2,5 \mu l$ de DNA

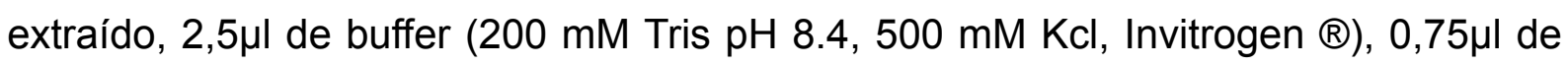

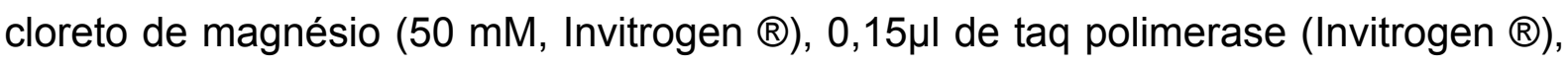
$4,0 \mu l$ de dNTP (Invitrogen $®$ ), 1,25 $\mu$ l de cada primer e 12,6 $\mu$ l de água de miliqui, de modo a totalizar $25 \mu \mathrm{l}$ por microtubo. 
Foi utilizado o aparelho termociclador modelo Mastercycler Gadient (Eppendorf $®$ ) com a seguinte sequência térmica: desnaturação inicial a $95^{\circ} \mathrm{C}$ por 5 minutos, seguida de 40 ciclos que consistiram em 30 segundos a $95^{\circ} \mathrm{C}, 30$ segundos a $48^{\circ} \mathrm{C}$ para anelamento e 40 segundos a $72^{\circ} \mathrm{C}$ para extensão, terminando a sequência com 7 minutos a $75^{\circ} \mathrm{C}$.

No caso da amostra positiva, foi realizado também o protocolo para o gene ompA das riquétsias do Grupo da Febre Maculosa utilizando os oligonucleotídeos iniciadores (primers) Rr190.70F (5'-ATGGCGAATATTTCTCCAAAA-3') e Rr190.602R (5'-AGTGCAGCATTCGCTCCCCCT-3') (REGNERY; SPRUIL; PLIKAYTIS, 1991).

Para a reação de amplificação foram utilizadas as mesmas quantidades de reagentes da reação anterior, apenas com substituição dos primers. $E$ a sequência térmica foi: desnaturação inicial a $95^{\circ} \mathrm{C}$ por 5 minutos, seguida de 35 ciclos que consistiram em 40 segundos a $95^{\circ} \mathrm{C}, 30$ segundos a $58^{\circ} \mathrm{C}$ para anelamento e 45 segundos a $72^{\circ} \mathrm{C}$ para extensão, terminando a sequência com 10 minutos a $75^{\circ} \mathrm{C}$.

Cada reação foi feita com no máximo 20 amostras por vez, utilizando dois controles negativos (reagentes e água de miliqui) e 1 controle positivo (Rickettsia sp. cepa NOD).

\subsubsection{PCR para Borrelia spp.}

A busca de DNA de bactérias do gênero Borrelia nas amostras de DNA extraídas das onças e dos carrapatos foi feita utilizando o mesmo protocolo de Stromdahl et al. (2003), uma nested-PCR para o gene da flagelina B, utilizando os primers FlaLL (5'ACATATTCAGATGCAGACAGAGGT-3') e FlaRL (5'GCAATCATAGCCATTGCAGATTGT-3') na primeira reação e os primers FlaLS (5'AACAGCTGAAGAGCTTGGAATG-3') e FlaRS (5'CTTTGATCACTTATCATTCTAATAGC-3') na segunda reação.

A reação de amplificação foi feita em microtubos de $200 \mu$ l adicionando $2,5 \mu l$ de DNA

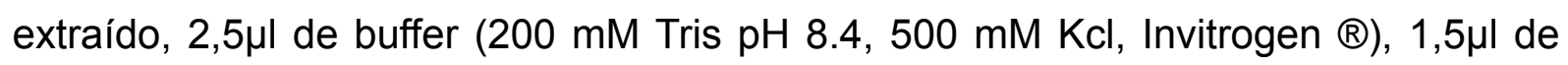

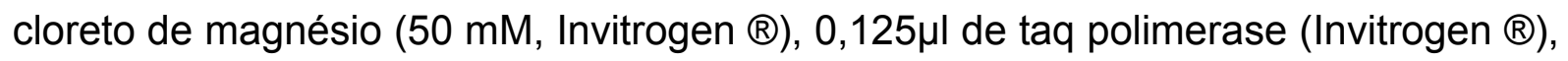

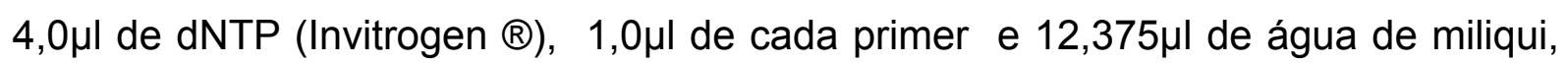
de modo a totalizar $25 \mu$. 
Para os dois ciclos foi utilizado o aparelho termociclador Mastercycler Gadient (Eppendorf $\circledR$ ) com a mesma sequência térmica de desnaturação inicial a $95^{\circ} \mathrm{C}$ por 3 minutos, seguida de 40 ciclos que consistiram em 1 minuto a $95^{\circ} \mathrm{C}, 1$ minuto a $65^{\circ} \mathrm{C}$ para anelamento e 1 minuto a $75^{\circ} \mathrm{C}$ para extensão, terminando a sequência com 10 minutos a $75^{\circ} \mathrm{C}$.

Cada reação foi feita com no máximo 20 amostras por vez, utilizando dois controles negativos (água de miliqui) e 1 controle positivo (B. anserina de cultivo celular).

\subsubsection{PCR para Ehrlichia spp.}

Para verificar a presença de DNA de bactérias do gênero Erhlichia nas amostras de DNA extraídas das onças e dos carrapatos foram utilizados os primers para o gene dsb: Dsb330 (5' -GATGATGTCTGAAGATATGAAACAAAT-3') e Dsb728 (5'CTGCTCGTCTATTTTACTTCTTAAAGT-3') (DOYLE et al., 2005).

A reação de amplificação foi feita em microtubos de $200 \mu$ l adicionando $2,5 \mu$ le DNA

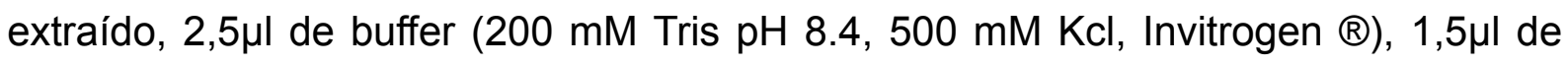
cloreto de magnésio (50 mM, Invitrogen $\left.{ }^{\circledR}\right), 0,15 \mu$ l de taq polimerase (Invitrogen $\left.{ }^{\circledR}\right)$,

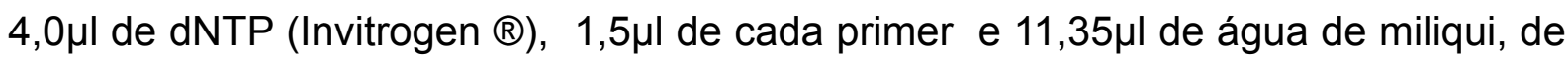
modo a totalizar $25 \mu \mathrm{l}$ por microtubo.

Foi utilizado o aparelho termociclador Mastercycler Gadient (Eppendorf $®$ ) com a seguinte sequência térmica: desnaturação inicial a $95^{\circ} \mathrm{C}$ por 3 minutos, seguida de 50 ciclos que consistiram em 15 segundos a $95^{\circ} \mathrm{C}, 30$ segundos a $58^{\circ} \mathrm{C}$ para anelamento e 30 segundos a $72^{\circ} \mathrm{C}$ para extensão, terminando a sequência com 5 minutos a $72^{\circ} \mathrm{C}$.

Cada reação foi feita com no máximo 20 amostras por vez, utilizando dois controles negativos (água de miliqui) e 1 controle positivo (Ehrlichia canis sequenciada de amostra de cão doméstico proveniente do estado do Espírito Santo). 


\subsubsection{PCR para família Anaplasmataceae}

Para verificar a presença de DNA de bactérias da família Anaplasmataceae nas amostras de DNA extraídas das onças e dos carrapatos foram utilizados os primers para o gene 16S rRNA GE2'F2' (5'-GTTAGTGGCAGACGGGTGAGT-3') and HE3 (5'TATAGGTACCGTCATTATCTTCCCTAT-3') (AGUIAR; HAGIWARA; LABRUNA, 2008).

A reação de amplificação foi feita em microtubos de $200 \mu$ l adicionando $2,5 \mu l$ de DNA

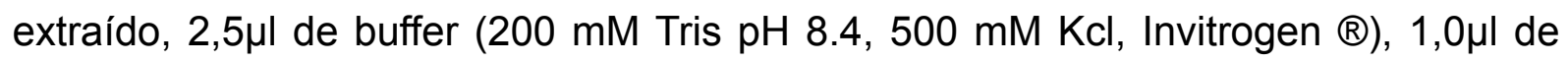

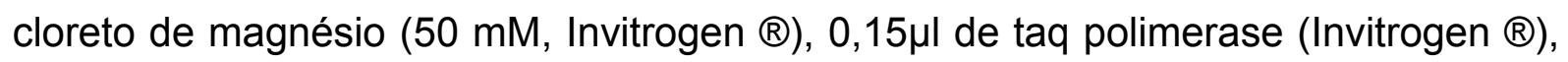

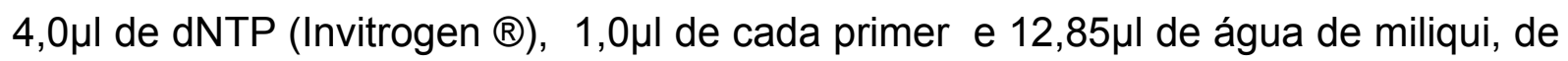
modo a totalizar $25 \mu$ por microtubo.

Foi utilizado o aparelho termociclador Mastercycler Gadient (Eppendorf $®)$ com a seguinte sequência térmica: desnaturação inicial a $95^{\circ} \mathrm{C}$ por 5 minutos, seguida de 35 ciclos que consistiram em 15 segundos a $95^{\circ} \mathrm{C}, 30$ segundos a $62^{\circ} \mathrm{C}$ para anelamento e 30 segundos a $72^{\circ} \mathrm{C}$ para extensão, terminando a sequência com 7 minutos a $72^{\circ} \mathrm{C}$.

Cada reação foi feita com no máximo 20 amostras por vez, utilizando dois controles negativos (água de miliqui) e 1 controle positivo (Ehrlichia canis sequenciada de amostra de cão doméstico proveniente do estado do Espírito Santo).

\subsubsection{PCR para Coxiella spp.}

Para busca de DNA de bactérias do gênero Coxiella nas amostras de DNA extraídas das onças e dos carrapatos foram utilizados os primers PryG-F (5'TTATTTACCAACGTTCCTGAGCCG-3') e PryG-R (5'TTTATCCCGAGCAAATTCAATTATGG-3') para amplificação do gene pyrG (REEVES et al., 2006).

A reação de amplificação foi feita em microtubos de $200 \mu$ l adicionando $2,5 \mu l$ de DNA

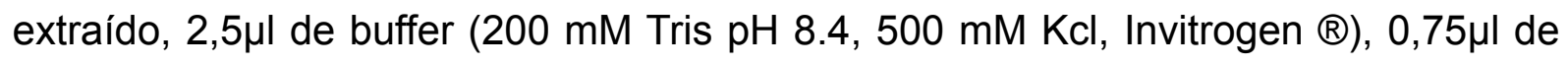

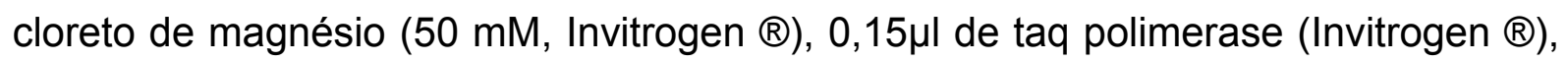




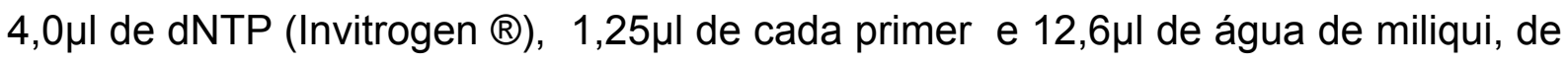
modo a totalizar $25 \mu$ por microtubo.

Foi utilizado o aparelho termociclador Mastercycler Gadient (Eppendorf $®$ ) com a seguinte sequência térmica: desnaturação inicial a $95^{\circ} \mathrm{C}$ por 5 minutos, seguida de 40 ciclos que consistiram em 1 minuto a $95^{\circ} \mathrm{C}, 1$ minuto a $60^{\circ} \mathrm{C}$ para anelamento e 35 segundos a $72^{\circ} \mathrm{C}$ para extensão, terminando a sequência com 7 minutos a $72^{\circ} \mathrm{C}$. Devido ao aparecimento de muitas bandas inespecíficas em algumas amostras, as mesmas foram testadas também pelos primers CAPI844-F (5'ATTTAGTGGGTTTCGCGCAT-3') e CAPI844-R (5'-CATCAGCATACGTTTCGGGAA3') para amplificação do gene da proteína sintetizadora do polissacarídeo capsular (REEVES et al., 2006).

Foram utilizadas as mesmas quantidades de reagentes da reação anterior, apenas com substituição dos primers. A sequência térmica utilizada foi: desnaturação inicial a $95^{\circ} \mathrm{C}$ por 5 minutos, seguida de 40 ciclos que consistiram em 1 minuto a $95^{\circ} \mathrm{C}, 1$ minuto a $55^{\circ} \mathrm{C}$ para anelamento e 4 segundos a $72^{\circ} \mathrm{C}$ para extensão, terminando a sequência com 10 minutos a $72^{\circ} \mathrm{C}$.

Cada reação foi feita com no máximo 20 amostras por vez, utilizando dois controles negativos (água de miliqui) e 1 controle positivo (Coxiella burnetti de cultivo celular COX Atg 5p).

\subsubsection{PCR para Hepatozoon spp.}

Para busca de DNA de protozoários do gênero Hepatozoon nas amostras de DNA extraídas das onças e dos carrapatos foram utilizados os primers HEP-1mod (5'CGCGAAATTACCCAATTCTA -3') And HEP-4 (5'TAAGGTGCTGAAGGAGTCGTTTAT-3') para amplificação de parte do gene 18S rRNA (SPOLIDORIO et al., 2009).

A reação de amplificação foi feita em microtubos de $200 \mu$ l adicionando $2,5 \mu$ l de DNA

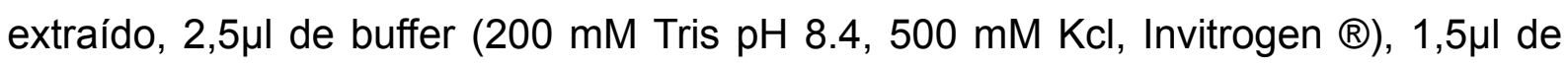
cloreto de magnésio (50 mM, Invitrogen $\left.{ }^{\circledR}\right), 0,125 \mu$ le taq polimerase (Invitrogen ${ }^{\circledR}$ ), $4,0 \mu l$ de dNTP (Invitrogen $\left.{ }^{\circledR}\right), 1,0 \mu l$ de cada primer e 12,375 $\mu$ l de água de miliqui, de modo a totalizar $25 \mu$ l por microtubo. 
Foi utilizado o aparelho termociclador Mastercycler Gadient (Eppendorf $®$ ) com a seguinte sequência térmica: desnaturação inicial a $95^{\circ} \mathrm{C}$ por 3 minutos, seguida de 40 ciclos que consistiram em 15 segundos a $95^{\circ} \mathrm{C}, 40$ segundos a $53^{\circ} \mathrm{C}$ para anelamento e 40 segundos a $72^{\circ} \mathrm{C}$ para extensão, terminando a sequência com 5 minutos a $72^{\circ} \mathrm{C}$.

Cada reação foi feita com no máximo 20 amostras por vez, utilizando dois controles negativos (água de miliqui) e 1 controle positivo (Hepatozoon canis sequenciado de amostra de cão doméstico do estado do Espírito Santo).

\subsubsection{PCR para Babesia spp.}

Para busca de DNA de protozoários do gênero Babesia nas amostras de DNA extraídas das onças e dos carrapatos foram utilizados os primers BAB-33-57 (5'GCCAGTAGTCATATGCTTGTCTTAA-3') e BAB-432-409 (5'TTCCTTAGATGTGGTAGCCGTTTC-3') para amplificação de parte do gene $18 \mathrm{~S}$ rRNA (SPOLIDORIO et al., 2009).

A reação de amplificação foi feita em microtubos de $200 \mu$ l adicionando $2,5 \mu l$ de DNA

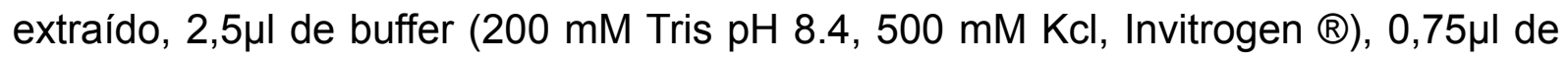
cloreto de magnésio (50 mM, Invitrogen $®), 0,15 \mu l$ de taq polimerase (Invitrogen $®$ ),

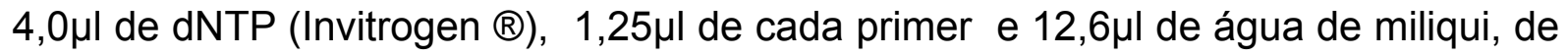
modo a totalizar $25 \mu \mathrm{l}$ por microtubo.

Foi utilizado o aparelho termociclador Mastercycler Gadient (Eppendorf $®$ ) com a seguinte sequência térmica: desnaturação inicial a $95^{\circ} \mathrm{C}$ por 3 minutos, seguida de 35 ciclos que consistiram em 15 segundos a $95^{\circ} \mathrm{C}, 30$ segundos a $63^{\circ} \mathrm{C}$ para anelamento e 30 segundos a $72^{\circ} \mathrm{C}$ para extensão, terminando a sequência com 7 minutos a $72^{\circ} \mathrm{C}$.

Cada reação foi feita com no máximo 20 amostras por vez, utilizando dois controles negativos (água de miliqui) e 1 controle positivo (Babesia canis sequenciada de amostra de cão doméstico do estado do Espírito Santo). 


\subsubsection{Eletroforese de DNA em gel de agarose}

Os produtos das reações, adicionados de corante (Gel Loading Buffer - Invitrogen ( )), foram submetidos à eletroforese horizontal em gel de agarose 1,5\% e tampão de corrida TBE 1X pH 8,0 (44,58 M Tris-base; 0,44 M ácido bórico; 12,49 mM EDTA) a $104 \mathrm{~V} / 45 \mathrm{~mA}$. Após isso, o gel era transferido para cuba com solução $0,5 \mu \mathrm{l} / \mathrm{mL}$ de brometo de etídeo (Invitrogen ${ }^{\circledR}$ ) por 10 a 30 minutos para corar. Os resultados foram visualizados por transiluminação por luz ultravioleta.

\subsubsection{Reação de sequenciamento genético e análise dos produtos}

Todas as amostras que apresentaram fragmentos amplificados de mesmo tamanho do controle positivo utilizado em cada reação foram sequenciadas, com exceção aos testes que apresentaram mais de 5 amostras positivas.

Estas amostras foram purificadas utilizando o ExoSAP-IT (USB Corporation ${ }^{\circledR}$ ) e submetidas ao sequenciamento genético utilizando o kit BigDye TM Terminator (Applied Biosystems ${ }^{\circledR}$ ), em ambos seguindo as orientações do fabricante.

À solução era então adicionado $40 \mu \mathrm{l}$ de isopropanol $65 \%$, e após homogenização a mistura era mantida por 20 minutos em temperatura ambiente para depois ser centrifugada a $14.000 \mathrm{rpm}$ por 25 minutos a $25^{\circ} \mathrm{C}$. O sobrenadante era descartado e $300 \mu \mathrm{l}$ de etanol $60 \%$ adicionado ao precipitado no tubo. A solução era novamente homogenizada e centrifugada a $14.000 \mathrm{~g}$ por 10 minutos a $25^{\circ} \mathrm{C}$. Após este procedimento o sobrenadante era mais uma vez descartado e o precipitado restante, que é o DNA, era seco em termobloco a $80^{\circ} \mathrm{C}$ por 2 minutos.

Cada amostra era então processada no sequenciador de DNA ABI Prism ${ }^{\text {TM }} 377$ DNA Sequencer (Applied Biosystems $\AA$ ), seguindo seu manual de instruções, e as sequências obtidas submetidas a análise de similaridade com as sequências disponíveis no GenBank através do programa Basic Local Alignment Search Tool (BLAST). 


\section{RESULTADOS}

Neste item são descritos os principais resultados obtidos por este projeto.

\subsection{CAPTURA, INSPEÇÃO E EXAME CLÍNICO}

Os dados mais relavantes sobre as onças-pintadas capturadas e resultados da inspeção e avaliação clínica estão descritos neste item.

\subsubsection{Dados gerais das 10 onças-pintadas capturadas}

Os dados obtidos acerca do sexo, idade estimada, eventuais achados reprodutivos e dados sobre o acompanhamento dos dez animais capturados estão detalhados no quadro 4.1.

Quadro 4.1 - Dados gerais sobre as onças capturadas. (continua)

\begin{tabular}{|c|c|c|c|c|}
\hline $\begin{array}{l}\text { Número } \\
\text { da onça }\end{array}$ & $\begin{array}{l}\text { Data de } \\
\text { captura }\end{array}$ & Sexo & Idade estimada & $\begin{array}{l}\text { Dados de acompanhamento (em setembro de } \\
\text { 2009) }\end{array}$ \\
\hline 1 & $20 / 06 / 08$ & fêmea & $\begin{array}{l}1,5 \text { anos } \\
\text { (subadulta) }\end{array}$ & Continua sendo acompanhada. \\
\hline 2 & $23 / 06 / 08$ & macho & $6-7$ anos & $\begin{array}{l}\text { Desaparecido (última localização } 2 \text { meses após } \\
\text { captura). }\end{array}$ \\
\hline 3 & $23 / 06 / 08$ & fêmea & $7-8$ anos & $\begin{array}{l}\text { Pariu uma semana após a captura. Foi } \\
\text { recapturada em julho de } 2009 \text {, estava } \\
\text { acompanhada de } 2 \text { filhotes de } 1 \text { ano e } \\
\text { continuava saudável. }\end{array}$ \\
\hline 4 & 05/07/08 & fêmea & 4 anos & $\begin{array}{l}\text { Pariu em novembro de } 2008 \text {, atualmente está } \\
\text { acompanhada de } 2 \text { filhotes. }\end{array}$ \\
\hline 5 & $16 / 07 / 08$ & fêmea & 6 meses (filhote) & $\begin{array}{l}\text { Foi acompanhada por apenas } 3 \text { meses } \\
\text { (retirada a coleira). }\end{array}$ \\
\hline 6 & $17 / 07 / 08$ & fêmea & $7-8$ anos & $\begin{array}{l}\text { Pariu } 2 \text { semanas após a captura e atualmente } \\
\text { está acompanhada de } 2 \text { filhotes. }\end{array}$ \\
\hline 7 & $25 / 07 / 08$ & macho & $6-7$ anos & Continua sendo acompanhado. \\
\hline 8 & $30 / 07 / 08$ & macho & $8-9$ anos & Óbito 3 meses após a captura. \\
\hline
\end{tabular}


Quadro 4.1 - Dados gerais sobre as onças capturadas. (conclusão)

\begin{tabular}{|l|l|l|l|l|}
\hline $\begin{array}{l}\text { Número } \\
\text { da onça }\end{array}$ & $\begin{array}{l}\text { Data de } \\
\text { captura }\end{array}$ & Sexo & Idade estimada & $\begin{array}{l}\text { Dados de acompanhamento (em setembro de } \\
\text { 2009) }\end{array}$ \\
\hline 9 & $04 / 08 / 08$ & fêmea & $3-4$ anos & $\begin{array}{l}\text { Desaparecida (última localização } 6 \text { meses após } \\
\text { a captura). } \\
\text { Recapturada após um ano para troca de } \\
\text { coleira, continuava saudável. }\end{array}$ \\
\hline 10 & $11 / 08 / 08$ & fêmea & $4-5$ anos & \\
\hline
\end{tabular}

Existem indícios de que os dois animais que desapareceram durante 0 monitoramento foram caçados ou envenenados em retaliação por causarem perdas econômicas às propriedades vizinhas devido à predação de gado.

\subsubsection{Inspeção e exame clínico}

As considerações clínicas foram:

- O estado geral de todos os animais era bom.

- Com exceção ao fato de 2 indivíduos (um macho e uma fêmea adultos) apresentarem mucosas levemente pálidas, nenhuma outra alteração relevante foi encontrada no exame clínico.

- O indivíduo número 8 teve a recuperação anestésica mais lenta que o esperado.

Sobre aspectos reprodutivos, os achados foram:

- As fêmeas 3 e 6 estavam prenhes (em terço final de gestação).

- A fêmea 10 apresentava discreto aumento uterino, podendo ser compatível com início de gestação, porém de acordo com o monitoramento deste animal não foi detectada a presença de filhotes dentro do período esperado (gestação de 96-104 dias). Na recaptura um ano depois foi detectada prenhez, mas ainda não foram feitas buscas para detectar a presença de filhotes.

- A fêmea 9 encontrava-se lactante com sinais característicos de estar amamentando, porém o(s) filhote(s) não foi(foram) avistado(s). 


\subsection{HEMOGRAMA E PERFIL BIOQUÍMICO}

Aqui são apresentados os valores medianos e intervalos interquartis calculados a partir dos resultados dos hemogramas e parâmetros bioquímicos das 10 onçaspintadas.

\subsubsection{Hemograma}

As medianas e intervalos interquartis dos parâmetros avaliados nos hemogramas das dez onças-pintadas estão descritos na tabela 4.2.

Tabela 4.2 - Valores medianos e intervalos interquartis dos hemogramas das onças capturadas

\begin{tabular}{lll}
\hline Parâmetro & Mediana & Intervalo Interquartil \\
\hline Glóbulos vermelhos $\left(1000 / \mathrm{mm}^{3}\right)$ & $7.515,0$ & $6.725,0-7.982,5$ \\
Hemoglobina (g/100dl) & 10,5 & $10,0-11,5$ \\
Hematócrito (\%) & 35,5 & $33,0-38,5$ \\
VCM (fl) & 48,5 & $47,0-49,75$ \\
HCM (pg) & 14,0 & $14,0-15,0$ \\
CHCM (g/dl) & 30,0 & $28,25-30,75$ \\
Plaquetas $(/ \mu l)$ & 239.000 & $183.000-293.750$ \\
Glóbulos brancos $\left(/ \mathrm{mm}^{3}\right)$ & $19.200,0$ & $15.475,0-23.250,0$ \\
Bastonetes $\left(/ \mathrm{mm}^{3}\right)$ & 868,0 & $477,75-1.458,5$ \\
Segmentados $\left(/ \mathrm{mm}^{3}\right)$ & $12.920,5$ & $10.967,0-16.353,0$ \\
Eosinófilos $\left(/ \mathrm{mm}^{3}\right)$ & 331,0 & $195,5-906,0$ \\
Basófilos $\left(/ \mathrm{mm}^{3}\right)$ & 0 & 0 \\
Linfócitos $\left(/ \mathrm{mm}^{3}\right)$ & $2.974,0$ & $2.412,5-3.825,5$ \\
Monócitos $\left(/ \mathrm{mm}^{3}\right)$ & 819,0 & $621,0-1.205,0$ \\
Mielócitos $\left(/ \mathrm{mm}^{3}\right)$ & 0 & 0 \\
Metamielócitos $\left(/ \mathrm{mm}^{3}\right)$ & 0 & 0 \\
\hline VCM - Volume corpuscular médio & \multicolumn{2}{l}{ HCM - Hemoglobina corpuscular média } \\
CHCM - Concentração de hemoglobina corpuscular média
\end{tabular}


Em comparação aos padrões humanos, todas as amostras de onças apresentaram anisocitose $(+++)$ e hipocromia (+). Nenhuma amostra apresentou granulações tóxicas ou outra consideração clínica relevante.

\subsubsection{Perfil bioquímico}

As medianas e intervalos interquartis obtidos na análise do perfil bioquímico das dez onças-pintadas estão descritos na tabela 4.3.

Tabela 4.3 - Valores medianos e intervalos interquartis calculados a partir dos resultados de perfil bioquímico das onças capturadas

\begin{tabular}{lll}
\hline Parâmetros & Mediana & Intervalo Interquartil \\
\hline Uréia $(\mathrm{mg} / \mathrm{dl})$ & 110,5 & $72,8-129,8$ \\
Creatinina $(\mathrm{mg} / \mathrm{dl})$ & 0,8 & $0,7-1,2$ \\
Fosfatase alcalina $(\mathrm{mg} / \mathrm{dl})$ & 30,0 & $19,5-53,0$ \\
AST $(\mathrm{U} / \mathrm{dl})$ & 43,0 & $39,0-53,0$ \\
ALT $(\mathrm{U} / \mathrm{dl})$ & 44.5 & $33,8-38,5$ \\
GGT $\left(\mathrm{U} / \mathrm{l}^{*}\right.$ & 10,0 & $8,0-11,0$ \\
Bilirrubina total $(\mathrm{mg} / \mathrm{dl})$ & 0,5 & $0,4-0,5$ \\
Bilirrubina direta $(\mathrm{mg} / \mathrm{dl})$ & 0,3 & $0,2-0,3$ \\
Bilirrubina indireta $(\mathrm{mg} / \mathrm{dl})$ & 0,2 & $0,2-0,2$ \\
CPK $(\mathrm{U} / \mathrm{l})$ & 294,0 & $158,3-545,3$ \\
Colesterol total $(\mathrm{mg} / \mathrm{dl})$ & 162,5 & $144,5-178,5$ \\
Triglicerídeos $(\mathrm{mg} / \mathrm{dl})$ & 45,5 & $37,3-61,3$ \\
Colesterol HDL $(\mathrm{mg} / \mathrm{dl})^{*}$ & 87,0 & $80,0-124,5$ \\
Ácido úrico $(\mathrm{mg} / \mathrm{dl})$ & 1,1 & $0,6-1,3$ \\
Proteínas totais $(\mathrm{g} / \mathrm{dl})$ & 7,4 & $7,2-7,8$ \\
Albumina $(\mathrm{g} / \mathrm{dl})$ & 2,5 & $2,3-2,6$ \\
Globulinas $(\mathrm{g} / \mathrm{dl})$ & 5,2 & $4,8-5,2$ \\
Ferro sérico $(\mu \mathrm{g} / \mathrm{dl})$ & 81,5 & $59,3-138,0$ \\
\hline
\end{tabular}

${ }^{*}$ Não realizados para os animais 1,2 e 3 .

Entre os resultados encontrados, chamaram a atenção o valor de Fosfatase alcalina $(192,0)$ obtido na amostra do animal 5 , e os valores de $\operatorname{ALT}(140,0)$ e AST $(160,0)$ para as amostras do animal 8. 


\subsection{ECTOPARASITAS}

A quantidade e espécies dos ectoparasitas coletados das onças-pintadas estão descritos abaixo.

\subsubsection{Carrapatos}

O número total de mediano de ectoparasitas encontrados em 3 minutos de busca foi 3,5 (variando de 0 a 9). Considerando coletas além deste tempo fixo, o número variou de 0 a 12 . No total foram coletados 40 carrapatos e 1 pulga.

Os carrapatos encontrados eram 3 larvas do gênero Amblyomma sp., 20 ninfas deste mesmo gênero e 1 de Boophilus spp., e entre os adultos: 4 fêmeas e 1 macho de Amblyomma triste e 6 fêmeas e 5 machos de Amblyomma cajenense.

\subsubsection{Pulgas}

Todas as onças apresentaram tungíase, com maior ou menor quantidade de lesões, em coxins palmares, plantares e dígitos. $O$ animal mais severamente acometido foi o indíviduo 1 , no qual foi possível coletar também a única pulga encontrada. 0 diagnóstico foi feito constatando lesões de aspecto clínico característico da penetração da fêmea da pulga Tunga penetrans na pele do hospedeiro, que foi confirmado em laboratório devido à identificação taxonômica da única pulga coletada, uma Tunga penetrans que não estava penetrada na pele do animal.

\subsection{PATÓGENOS VEICULADOS POR ARTRÓPODES}

Os resultados obtidos na busca por hemoparasitas em esfregaço sanguíneo e 
resultados dos testes sorológicos e moleculares realizados estão descritos neste item.

\subsubsection{Busca por hemoparasitas em esfregaço sanguíneo}

De acordo com a leitura feita pelo laboratório de análises clínicas, em nenhuma das lâminas de esfregaço sanguíneo foram encontrados hemoparasitas.

\subsubsection{Sorologias}

Os resultados sorológicos (RIFI), dos testes realizados no Laboratório de Doenças Parasitárias da FMVZ/USP para espécies do gênero Rickettsia testados, apresentaram as seguintes titulações (Tabela 4.4):

Tabela 4.4 - Títulos sorológicos das onças-pintadas para as 6 Rickettsia spp. testadas.

\begin{tabular}{lllllll}
\hline $\begin{array}{l}\text { Número da } \\
\text { onça }\end{array}$ & $\begin{array}{l}\text { Rickettsia } \\
\text { rickettsii }\end{array}$ & $\begin{array}{l}\text { Rickettsia } \\
\text { parkeri }\end{array}$ & $\begin{array}{l}\text { Rickettsia } \\
\text { rhipicephalii }\end{array}$ & $\begin{array}{l}\text { Rickettsia } \\
\text { amblyomii }\end{array}$ & $\begin{array}{c}\text { Rickettsia felis } \\
\text { Rickettsia } \\
\text { bellii }\end{array}$ \\
\hline 1 & 128 & 128 & $<64$ & 64 & $<64$ & 128 \\
2 & 256 & 256 & 256 & 256 & $<64$ & 64 \\
3 & 256 & 128 & 256 & 128 & 64 & $<64$ \\
4 & 128 & 128 & 256 & 128 & $<64$ & $<64$ \\
5 & $<64$ & $<64$ & $<64$ & $<64$ & $<64$ & 512 \\
6 & 128 & 2048 & 256 & 128 & 64 & 128 \\
7 & 128 & 64 & 64 & 64 & $<64$ & $<64$ \\
8 & 128 & 128 & 128 & 128 & $<64$ & $<64$ \\
9 & 128 & 256 & 128 & 128 & $<64$ & $<64$ \\
10 & 128 & 128 & 512 & 1024 & 64 & $<64$ \\
\hline
\end{tabular}

Na reação de imunofluorescência indireta para Ehrlichia canis, os indivíduos 2 e 4 apresentaram titulação sorológica de 64 e os indivíduos 3 e 10 de 256, os outros indivíduos foram não reagentes já na primeira diluição (1:64). 


\subsubsection{Testes pela reação em cadeia pela polimerase}

Todas as amostras das onça e de carrapatos e "pools" de ninfas coletados foram testados pela reação em cadeia pela polimerase para patógenos dos gêneros Rickettsia, Ehrlichia, Coxiella, Hepatozoon, Borrelia, Babesia e família Anaplasmataceae.

\subsubsection{Resultados obtidos nas amostras de sangue das onças}

As amostras das onças foram todas positivas para Hepatozoon. Cinco amostras foram então sequenciadas, apresentando $98 \%$ de similaridade com Hepatozoon felis (AY628681).

A amostra do animal 8 apresentou banda fraca na eletroforese da PCR para Anaplasmataceae, porém não foi possível clonar este material para sequenciamento durante as análises em laboratório.

Todas as amostras foram consideradas negativas para o gênero Babesia, porém apresentaram uma banda forte de peso molecular maior que o controle positivo na eletroforese da PCR para amplificação do gene 18S rRNA para o gênero Babesia. Duas amostras foram então sequenciadas, apresentando $98 \%$ de similaridade com Cytauxzoon felis (AY679105, AF399930).

As amostras de onças foram consideradas negativas nas PCRs utilizadas para detecção de patógenos dos gêneros Rickettsia, Ehrlichia, Coxiella e Borrelia.

4.4.3.2 Resultados obtidos nas amostras provenientes dos carrapatos coletados das onças

Uma fêmea de Amblyomma triste foi positiva na PCR para o gênero Rickettsia e também para a PCR específica para o grupo da febre maculosa, e a sequência genética obtida teve $100 \%$ de similaridade com Rickettsia parkeri cepa At24 ompA 
(EF102238).

Uma fêmea e dois machos de Amblyomma cajennense apresentaram banda fraca na eletroforese da PCR para o gene da proteína sintetizadora do polissacarídeo capsular do gênero Coxiella, porém não foi possível clonar este material para sequenciamento durante as análises em laboratório.

Indivíduos adultos de $A$. cajennense e $A$. triste, pools de ninfas do gênero Amblyomma e a ninfa do gênero Boophilus foram positivas na PCR para o gênero Hepatozoon. Cinco amostras foram sequenciadas e apresentaram 98\% de similaridade com Hepatozoon felis (AY628681).

Assim como ocorreu com as onças, os carrapatos foram todos negativos na PCR para o gênero Babesia, porém as amostras obtidas de adultos de $A$. cajennense e $A$. triste, pools de ninfas e larvas do gênero Amblyomma e a ninfa do gênero Boophilus apresentaram à eletroforese a mesma banda forte de peso molecular maior que 0 esperado, sendo compatível com Cytauxzoon felis.

Quando testadas na PCR para a família Anaplasmataceae, uma fêmea de A. triste e uma de $A$. cajennense, provenientes de onças diferentes, foram consideradas positivas. Ambas amostras foram sequenciadas e apresentaram $99 \%$ de similaridade com Ehrlichia sp. (AY30970, FJ966350) e 98\% de similaridade com Ehlichia ruminantium (diversas sequências). Estas e as outras amostras foram negativas na PCR para o gene DSB do gênero Ehrlichia.

Todas as amostras de carrapatos foram negativas na PCR para o gênero Borrelia.

\subsection{SOROLOGIA PARA O VÍRUS DA RAIVA}

Os resultados obtidos no teste sorológico das 10 onças foram 8 onças com título menor que $0,08 \mathrm{UI}$, e as onças 6 e 8 com título de $0,12 \mathrm{UI}$. 


\section{DISCUSSÃo}

Neste tópico são discutidos os resultados obtidos referentes às avaliações clínicas e laboratoriais acerca da saúde da população de onças-pintadas estudada.

\subsection{PERFIL CLÍNICO}

Este é o primeiro estudo com onças-pintadas de vida livre a obter os dados de hemograma e perfil bioquímico. Estes dados são fundamentais para futuramente estabelecer os valores normais para esta espécie ameaçada de extinção, possibilitando avaliar a saúde dos indivíduos e populações, e facilitando a detecção de situações de risco populacional, tais como emergência de doenças (CURRIER; RUSSELL, 1982; DUNBAR; NOL; LINDA, 1997).

Em virtude do tamanho amostral não ser tão elevado, os animais serem de idades variadas, e as amostras terem sido coletadas sob efeito de estresse e contenção anestésica, os valores obtidos não podem ser considerados como o normal para onças-pintadas (KOCAN; BLOUIN, 1985). Um exemplo disso é o elevado número de leucócitos encontrado nestes animais comparado aos dados obtidos de animais de cativeiro (HAWKEY; HART, 1986), o que talvez seja explicado por um maior estresse durante a contenção. Porém, mesmo considerando que estas limitações dificultem a avaliação individual dos animais utilizados neste estudo, alguns dados obtidos nestes exames corroboram com achados clínicos, são eles:

- O valor da fosfatase alcalina na amostra da onça-pintada número 5 , um filhote de 6 meses, era seis vezes maior que a mediana obtida pelas amostras de todas as onças. Este achado é comum também em filhotes de gatos domésticos, nos quais o aumento é devido à intensa atividade osteoblástica (THRALL, 2006).

- Os valores de ALT e AST encontrados na amostra do animal número 8, um macho adulto de idade estimada entre 8 e 9 anos, eram pelo menos três vezes maiores que as medianas obtidas das amostras de todas as onças, porém outros parâmetros como creatinofosfoquinase (CPK), fosfatase alcalina 
e gama glutamil transferase (GGT) encontravam-se dentro dos intervalos interquartis obtidos a partir dos 10 animais. Este indivíduo apresentou longa recuperação anestésica, o dobro do apresentado pelos outros animais com a mesma dose da associação de tiletamina e zolazepam (de metabolização hepática), e veio a óbito 3 meses após a captura. Como o local de morte era de difícil acesso, não foi possível recuperar a carcaça a tempo de realizar a necrópsia, impedindo assim conclusões definitivas; porém, os resultados aqui apresentados indicam uma lesão hepática, provavelmente focal ou multifocal (THRALL, 2006).

Os resultados obtidos indicam que, com exceção ao animal número 8 , as onçaspintadas capturadas estavam em boas condições de saúde geral. Nesta avaliação foram levados em conta não apenas os dados obtidos no exame clínico, mas também os resultados laboratoriais e de monitoramento dos indivíduos.

\subsection{ECTOPARASITAS}

Esta população de onças-pintadas apresentou baixa infestação por carrapatos se comparada ao valor médio obtido em um estudo no Paraguai com esta espécie (DURDEN et al., 2006). As espécies encontradas, Amblyomma cajennense, A. triste e Rhipicephalus (Boophilus) microplus já são descritos parasitando onças-pintadas, sendo o terceiro um indicativo da relação predador-presa entre as onças pintadas e o gado (LABRUNA et al., 2005).

Um dos achados durante a execução deste projeto foi a ocorrência de tungíase em onças-pintadas, doença que ainda não havia sido relatada para a espécie (WIDMER; AZEVEDO, 2009).

\subsection{PATÓGENOS VEICULADOS POR ARTRÓPODES}

Apesar de todos os animais serem positivos para Cytauxzoon felis e Hepatozoon sp., nenhuma das lâminas de esfregaço sanguíneo foi positiva. Este resultado é 
semelhante ao encontrado em outros estudos que demonstram a baixa sensibilidade deste teste (CRIADO-FORNELIO et al., 2007; CRIADO-FORNELIO et al., 2009). Um dos achados neste projeto foi a detecção de Cytauxzoon felis através da utilização dos primers BAB33-57 e BAB432-409, desenvolvidos para amplificação de parte do gene 18S rRNA de protozoários do gênero Babesia (SPOLIDORIO et al., 2009), o que possibilita a pesquisa destes dois agentes utilizando o mesmo protocolo, apenas utilizando como referência os pesos moleculares para diferenciação.

\subsubsection{Gênero Rickettsia}

Este é o primeiro estudo a apresentar evidências sorológicas da infecção de onçaspintadas por Rickettsia spp. e a sequenciar Rickettsia parkeri a partir de um carrapato que estava parasitando uma onça-pintada. De acordo com os resultados sorológicos é possível inferir que todas as onças tiveram contato com pelo menos uma espécie do gênero Rickettsia.

Foi possível caracterizar a sorologia positiva para Rickettsia bellii (ou agente de antigenicidade semelhante) no indivíduo 5, o qual foi considerado positivo para apenas esta riquétsia.

Também foi possível caracterizar a sorologia positiva para Rickettsia parkeri no indivíduo 6, que apresentou titulação sorológica 8 vezes maior que para as outras espécies testadas. No caso deste animal, a suspeita de contato com a espécie Rickettsia parkeri é confirmada por haver provas de que esta população tem contato com este agente, devido ao sequenciamento genético desta riquétsia em um carrapato coletado em outro animal deste estudo. A espécie de carrapato infectada com esta riquétsia, Amblyomma triste, é reconhecida como vetor desta doença (VENZAL et al., 2008).

No caso do animal número 10, que apresentou titulação sorológica de 512 para $R$. rhipicephalii e de 1024 para R. amblyommii, é possível concluir que este animal teve contato com um destes dois agentes, ou de alguma espécie de antigenicidade muito semelhante. Estas duas riquétsias tem ocorrência relatada no Brasil, porém não no 
Pantanal, provavelmente por falta de estudos.

A patogenicidade de $R$. bellii, R. rhipicephalii e R. amblyommii para seres humanos é desconhecida (LABRUNA et al., 2007; PAROLA; LABRUNA; RAOULT, 2009), porém a R. parkeri, que faz parte das riquétsias do Grupo da Febre Maculosa, é reconhecida como patogênica ao ser humano, tendo como principais sintomas febre, escara de inoculação, mialgia, rash cutâneo (principalmente máculas ou pápulas) e dores de cabeça (PADDOCK et al., 2008). Sendo portanto necessário que moradores locais e turistas sejam advertidos sobre a importância de prevenir picadas de carrapatos e sejam orientados para buscar auxílio médico se apresentarem algum dos sintomas da doença.

\subsubsection{Gênero Borrelia}

Não foi detectada nenhuma amostra de onça ou carrapato positiva na reação em cadeia pela polimerase para o gênero Borrelia. Este resultado era esperado, uma vez que o agente da Doença de Lyme nunca foi isolado no Brasil. Porém, como no estado do Mato Grosso do Sul existem casos humanos de caracterização sorológica e clínica de infecção por Borrelia sp. (NAKA et al., 2008), a chamada Doença de Lyme-Símile (YOSHINARI et al., 2003), seria interessante realizar testes sorológicos nas amostras desta população de onças-pintadas para verificar se estes animais têm contato com patógenos deste gênero. Se os animais forem positivos, isso seria indicativo da presença do agente nesta região, tornando necessárias medidas de vigilância da Doença de Lyme-Símile em moradores locais e turistas.

\subsubsection{Gênero Coxiella}

Três espécimes adultos de Amblyomma cajennense apresentaram banda fraca na eletroforese da PCR para Coxiella, porém por indisponibilidade de tempo e material estas amostras ainda não puderam ser clonadas e sequenciadas, não sendo possível afirmar que seja Coxiella burnetti, o agente causador da Febre $Q$. 
Independente deste resultado, devido à importância desta doença para saúde pública (RAOULT et al., 1990; MAURIN; RAOULT, 1999), seria de grande relevância monitorar a presença deste agente nos trabalhadores da região, uma vez que a principal atividade econômica local é a criação de gado e portanto a maioria dos moradores estão envolvidos em trabalho direto com estes animais. É necessário também pesquisar a ocorrência deste patógeno em outras espécies de animais silvestres e carrapatos, de forma a esclarecer se existem e quais são os reservatórios e transmissores deste nesta região.

\subsubsection{Família Anaplasmataceae}

Este estudo relata a descoberta de uma possível nova espécie de erlíquia. Esta foi sequenciada a partir de dois carrapatos, um Amblyomma cajennense e um Amblyomma triste coletados de onças diferentes, que foram positivos na PCR para o gene $16 \mathrm{~S}$ rRNA da família Anaplasmataceae. Serão feitas tentativas de isolamento deste material a partir de novas amostras coletadas. São necessários também estudos para elucidar quais as espécies reservatório e transmissoras deste agente.

A presença deste agente em carrapatos que estavam parasitando as onças leva à suspeita de que a sorologia considerada positiva (titulação a partir de 1:64) de quatro animais para Ehrlichia canis é resultante de uma reação cruzada. Esta suspeita reforça a necessidade de sempre complementar estudos sorológicos com a tentativa de recuperar os microorganimos (MURRAY et al., 1999), pois muitas espécies silvestres que apresentam sorologia positiva para Ehrlichia canis, sugerindo por exemplo contato com cães domésticos, podem na verdade ter sido infectadas por uma espécie nativa de erlíquia.

A amostra de sangue da onça número 8 apresentou banda fraca na eletroforese desta PCR, porém por indisponibilidade de tempo e material esta amostra ainda não pôde ser clonada e sequenciada. No caso deste animal, uma suspeita é que a infecção fosse recente, pois ele não apresentou soropositividade na reação de imunofluorescência indireta para Ehrlichia canis. Este mesmo animal apresentou no dia da captura indícios clínicos e de perfil bioquímico que sugeriram presença de lesão hepática, e veio a óbito 3 meses após estes exames. Porém, como não foi 
possível estabelecer a causa de morte, e não foram feitos testes para outros agentes e fatores que poderiam acarretar o quadro clínico apresentado - até mesmo para excluir um fator relacionado à idade do animal -, não é possível concluir que a Ehrlichia sp. esteja envolvida no quadro apresentado. Mais estudos são necessários para elucidar a possível patogenicidade deste agente para a onça-pintada e outras espécies silvestres.

Por existirem outras erlíquias patogênicas de relevância em saúde pública (LEPIDI et al., 2000; BAKKEN; DUMLER, 2006), são recomendados estudos para verificar a potencial patogenicidade desta possível nova espécie ao ser humano.

\subsubsection{Gênero Babesia}

Não foi detectada nenhuma amostra de onça ou carrapato positivo na reação em cadeia pela polimerase para o gênero Babesia. Porém, por agentes deste gênero já terem sido detectados em onças-pintadas de cativeiro através de testes sorológicos (ANDRÉ, 2008), e por haver patógenos deste gênero relacionados a morbidade e mortalidade em leões por co-infecção com agente viral (MUNSON et al., 2008), seria interessante realizar testes sorológicos nas amostras desta população para verificar se estes animais têm contato com patógenos deste gênero.

\subsubsection{Gênero Cytauxzoon}

Foi detectada presença de DNA de Cytauxzoon sp., com 98\% de similaridade a C. felis, em amostras de sangue de todas as onças capturadas neste projeto e, por se tratar de uma população aparentemente saudável (ver perfil clínico), este resultado é sugestivo de que a espécie seja reservatório deste agente. Este é o primeiro relato de Cytauxzoon sp. em onças-pintadas de vida livre.

$\mathrm{Na}$ maioria dos carrapatos, incluindo exemplares das 3 espécies coletadas $(A$. cajennense, A. triste e Rhipicephalus (Boophilus) microplus), também foi detectada a presença de DNA para este agente. Porém como estes carrapatos estavam se 
alimentando nas onças infectadas, não é possível determinar se os carrapatos estavam infectados com este agente. Mais estudos são necessários para verificar a capacidade destas espécies de se infectar e de transmitir este patógeno.

Por ser a espécie C. felis patogênica para outras espécies de felídeos (JACKSON; FISHER, 2006; PEIXOTO et al., 2007), incluindo a espécie considerada reservatório deste patógeno nos Estados Unidos (NIETFELD; POLLOCK, 2002), é necessário um maior acompanhamento dos animais infectados por este Cytauxzoon sp. semelhante a esta espécie e a pesquisa deste agente em onças-pintadas de outras regiões para esclarecer se este protozoário pode ser uma ameaça à saúde deste felídeo. São recomendadas também medidas profiláticas no caso de translocação ou de encaminhamento de onças-pintadas desta região para centros de triagem e/ou reabilitação ou zoológicos, de forma a evitar o contágio de indivíduos sensíveis a este agente.

\subsubsection{Gênero Hepatozoon}

Como no teste anterior, também foi detectada a presença de DNA de Hepatozoon sp., com $98 \%$ de similaridade a Hepatozoon felis, em amostras de sangue de todas as onças-pintadas, o que é sugestivo de que a espécie seja reservatório deste agente. Este é o primeiro relato desta Hepatozoon sp. em onças-pintadas. Assim como relatado em leões (Panthera leo) infectados por Hepatozoon felis na Tanzânia (MUNSON et al., 2008), aparentemente a infecção por este agente é assintomática em onças-pintadas.

A maioria dos carrapatos, incluindo exemplares das 3 espécies coletadas $(A$. cajennense, A. triste e Rhipicephalus (Boophilus) microplus), foram positivos na PCR para este agente. Porém como estes carrapatos estavam se alimentando nas onças infectadas, não é possível determinar se os carrapatos estavam infectados com este agente. Mais estudos são necessários para verificar a possível infecção destes artrópodes por esta Hepatozoon sp., pois como a transmissão de Hepatozoon spp. é através da ingestão do artrópode infectado (BANETH et al., 1998), é possível que estas 3 espécies de carrapato sejam veiculadores deste patógeno caso sejam ingeridos por outro animal. 
Como a patogenicidade deste agente não é totalmente esclarecida, são recomendadas medidas profiláticas no caso de translocação ou de encaminhamento de onças-pintadas desta região para centros de triagem e/ou reabilitação ou zoológicos, de forma a evitar o contágio de indivíduos que nunca tiveram contato com este agente.

\subsection{RAIVA}

O título sorológico considerado como protetor para pessoas e animais vacinados para raiva é de 0,50UI (SÃO PAULO, 2009; COMUNIDADE EUROPÉIA, 2003). No entanto, mesmo títulos abaixo deste podem significar contato prévio com antígeno, como já demonstrado em guaxinins (Procyon lotor) nos Estados Unidos (HILL; BERAN; CLARK, 1992).

Este é o primeiro relato de onças-pintadas soropositivas para o vírus da raiva. Os dois animais (indivíduos 6 e 8 ) apresentaram baixo título sorológico (0,12 UI) e não apresentavam sintomas compatíveis com a raiva no dia da captura. A fêmea número 6 vem sendo monitorada há mais de um ano, e não apresenta qualquer alteração perceptível de saúde. O animal número 8 é o macho que apresentou achados clínicos compatíveis com lesão hepática (ver perfil clínico) e que veio a óbito 3 meses após a captura, sem definição da causa, não sendo possível inferir sobre possíveis efeitos do vírus na saúde do animal.

Baixos títulos de anticorpos neutralizantes já foram detectados em outras espécies de carnívoros (EAST et al., 2001; DEEM; DAVIS; PACHECO, 2004), incluindo animais brasileiros de vida livre aparentemente saudáveis e não vacinados (JORGE, 2008), o que fortalece a suspeita de que o baixo título de anticorpos nestas duas onças provavelmente é resultante de uma infecção não letal. A menor letalidade pode ser devido a uma infecção por uma variante viral menos virulenta ou que tenha coevoluído com este hospedeiro; ou resultante da passagem do vírus por hospedeiro heterólogo ou pelo modo como o animal se infectou (EAST et al., 2001).

Mais estudos são necessários para melhor avaliar este contato das onças-pintadas com o vírus da raiva, bem como descobrir com qual estirpe viral esta população tem contato. 


\subsection{SAÚDE POPULACIONAL}

Todos os animais foram considerados saudáveis e com boa condição corporal durante a inspeção e exame clínico. $O$ animal número 8 foi o único a apresentar indícios de algum processo patológico, porém foi também o animal mais velho a ser capturado (idade estimada entre 8 e 9 anos).

Através dos dados ecológicos é possível inferir que estes animais têm um bom sucesso reprodutivo e boa sobrevivência de filhotes, uma vez que três das quatro fêmeas em idade fértil que estão sendo monitoradas estão acompanhadas de dois filhotes cada, e estes já estão chegando à fase juvenil. A única fêmea que não foi detectada com filhotes teve sua prenhez diagnosticada em uma recaptura em julho de 2009, mas ainda não foram feitas buscas para detectar a presença de filhotes.

Apesar deste trabalho ser baseado em apenas 10 animais e em um monitoramento de apenas um ano, estes dados, somados aos indícios de que os dois animais desaparecidos foram abatidos como retaliação a predação de gado, sugerem que doenças provavelmente não são uma grande ameaça a esta população no momento. Esta constatação reforça a hipótese de que os conflitos com os criadores de gado são a principal causa de mortalidade para a espécie nesta região (QUIGLEY; CRAWSHAW, 1991). Porém, como muito pouco é conhecido sobre o papel da maioria dos patógenos nas dinâmicas populacionais de carnívoros, especialmente quando os efeitos são não-epidêmicos ou aparentemente não letais ou então agravados através de interações com outros fatores ou doenças (MURRAY et al., 1999), não é possível dizer que estes patógenos não afetam estes animais, sendo necessárias mais pesquisas e um melhor monitoramento sobre a ocorrência e efeitos destes e outros agentes infecciosos para esta espécie, assim como o monitoramento e controle para evitar a introdução de agentes novos potencialmente patogênicos a esta espécie. 


\section{CONCLUSÕES}

- Este é o primeiro estudo com onças-pintadas de vida livre a relatar dados de hemograma e perfil bioquímico para a espécie.

- Este é o primeiro estudo a apresentar evidências sorológicas da infecção de onças-pintadas por Rickettsia spp. e a sequenciar Rickettsia parkeri a partir de um carrapato que estava parasitando uma onça-pintada.

- Na área estudada existe uma Ehrlichia sp. possivelmente ainda não relatada, a qual foi detectada em carrapatos adultos das espécies Amblyomma cajenense e Amblyomma triste.

- A Ehrlichia sp. detectada neste estudo não é detectada pela PCR para amplificação do gene $d s b$ do protocolo de Doyle et al. (2005).

- Todas as onças estudadas e a maioria dos carrapatos pesquisados (incluindo exemplares de $A$. cajenense, $A$. triste e Rhipicephalus (Boophilus) microplus) apresentaram fragmentos de DNA de Cytauxzoon sp., com $98 \%$ de similaridade a C. felis.

- Todas as onças estudadas e a maioria dos carrapatos pesquisados (incluindo exemplares de $A$. cajenense, $A$. triste e Rhipicephalus (Boophilus) microplus) apresentaram fragmentos de DNA de Hepatozoon sp., com $98 \%$ de similaridade a Hepatozoon felis.

- As onças-pintadas da área estudada estão expostas ao vírus rábico.

- O protocolo utilizado para amplificação de parte do gene 18S rRNA de protozoários do gênero Babesia (primers BAB33-57 e BAB432-409, SPOLIDORIO et al., 2009) pode ser utilizado para detecção de protoários da espécie Cytauxzoon sp. relatada neste estudo.

- É recomendada a realização de teste diagnóstico para os gêneros Cytauxzoon e Hepatozoon, e profilaxia de infestação por ectoparasitas em onças-pintadas que eventualmente tenham que ser encaminhadas a zoológicos ou centros de triagem e que sejam procedentes da região onde foi desenvolvido este projeto; assim como avaliar a possível introdução deste agente em áreas para onde estes animais possam ser translocados.

- São necessárias mais pesquisas sobre o contato de onças-pintadas com o 
vírus da raiva e os possíveis impactos deste patógeno nas populações silvestres nesta região do Pantanal.

- São necessários mais estudos sobre o papel da onça-pintada como reservatório das espécies de Cytauxzoon e Hepatozoon relatadas neste estudo.

- São necessárias pesquisas com $A$. cajenense, $A$. triste e Rhipicephalus (Boophilus) microplus para verificar se estes artrópodes se infectam por Cytauxzoon sp. e Hepatozoon sp., e se estas espécies atuam como reservatórios e/ou transmissores destes agentes.

- São recomendados estudos acerca da possível patogenicidade da Ehrlichia sp. encontrada neste estudo.

- É recomendado um programa de vigilância de casos humanos e animais de riquetsioses na área de estudo.

- São necessários mais estudos para esclarecer a presença de bactérias do gênero Coxiella na região de estudo. 


\section{REFERÊNCIAS}

AGUIAR, D.; HAGIWAR, M.; LABRUNA, M. In vitro isolation and molecular characterization of an Ehrlichia canis strain from São Paulo, Brazil. Brazilian Journal of Microbiology, v. 39, p. 489-493, 2008.

AGUIRRE, A. A. Wild canids as sentinels of ecological health: a conservation medicine perspective. Parasite \& Vectors, v. 2, p. S7, 2009. Suplemment, 1. Disponível em: < http://www.ncbi.nlm.nih.gov/pmc/articles/PMC2679399/>. Acesso em: 04 nov. 2009.

AGUIRRE, A. A; OSTFELD, R. S.; TABOR, G. M.; HOUSE, C.; PEARL, M. C. Conservation medicine: ecological health in practice. Oxford: Oxford University press, 2002. 432p.

ALECRIM, I.; PINTO, B.; ÁVILA, T.; COSTA, R.; PESSOA, I. Registro do primeiro caso de infecção humana por Babesia spp. no Brasil. Revista de Patologia Tropical, v. 12, p. 11-29, 1983.

ANDRÉ, M. R. Detecção molecular e sorológica de Ehrlichia canis e Babesia canis em felídeos selvagens brasileiros mantidos em cativeiro. 2008. 78p.

Dissertação (mestrado) - Faculdade de Medicina Veterinária e Zootecnia, Universidade Estadual Paulista, Jaboticabal, 2008.

ANDRÉ, M. R.; ADANIA, C. H.; MACHADO, R. Z.; ALLEGRETTI, S. M.; FELIPPE, P. A. N.; SILVA, K. F.; NAKAGHI, A. C. H.; DAGNONE, A. S. Molecular detection of Cytauxzoon spp. in asymptomatic Brazilian wild captive felids. Journal of Wildlife Diseases, v. 45, n. 1, p. 234-237, 2009.

ANGERAMI, R. N.; RESENDE, M. R.; FELTRIN, A. F.; KATZ, G.; NASCIMENTO, E. M.; STUCCHI, R. S. B.; SILVA, L. J. Brazilian spotted fever: a case series from an endemic area in southeastern Brazil: clinical aspects. Annals of the New York Academy of Sciences, v. 1078, p. 252-254, 2006.

APPEL, M. J.; YATES, R. A.; FOLEY, G. L.; BERNSTEIN, J. J.; SANTINELLI, S.; SPELMAN, L. H.; MILLER, L. D.; ARP, L. H.; ANDERSON, M.; BARR, M. Canine distemper epizootic in lions, tigers, and leopards in North America. Journal of Veterinary Diagnostic Investigation, v. 6, n. 3, p. 277-288, 1994.

AZEVEDO, F.; MURRAY, D. Spatial organization and food habits of jaguars (Panthera onca) in a floodplain forest. Biological Conservation, v. 137, n. 3, p. 391- 
402, 2007.

BABUDIERI, B. Q fever: a zoonosis. Advances in Veterinary Science, v. 5, p. 81, 1959.

BAKKEN, J. S.; DUMLER, J. S. Clinical diagnosis and treatment of human granulocytotropic anaplasmosis. Annals of the New York Academy of Sciences, v. 1078, n. 1, p. 236-247, 2006.

BANETH, G.; AROCH, I.; TAL, N.; HARRUS, S. Hepatozoon species infection in domestic cats: a retrospective study. Veterinary Parasitology, v. 79, n. 2, p. 123133, 1998.

BARROS-BATTESTI, D. M.; ARZUA, M.; BECHARA, G. H. Carrapatos de importância médico-veterinária da região Neotropical: um guia ilustrado para identificação de espécies. São Paulo: Vox/ICTTD-3/Butantan, 2006. 223p.

BATISTA, H. B. C. R.; VICENTINI F. K.; FRANCO A. C.; SPILKI F. R.; SILVA J. C. R.; ADANIA C. H.; ROEHE, P. M. Neutralizing antibodies against feline herpervirus type 1 in captive wild felids of Brazil. Journal of Zoo and Wildlife Medicine, v. 36, p. 447-450, 2005.

BEGON, M.; TOWNSEND, C. R.; HARPER, J. L. Ecology: from individuals to ecosystems. 4. Ed. Singapura: Blackwell Publishing, 2006. 738p.

BERNARDI, F.; NADIN-DAVIS, S. A.; WANDELER, A. I.; ARMSTRONG, J.; GOMES, A. A.; LIMA, F. S.; NOGUEIRA, F. R.; ITO, F. H. Antigenic and genetic characterization of rabies viruses isolated from domestic and wild animals of Brazil identifies the hoary fox as a rabies reservoir. Journal of General Virology, v. 86, p. 3153-3162, 2005.

BRASIL. Ministério da Saúde. Secretaria de Vigilância em Saúde. Casos confirmados de Rickettsioses. 2009a. Disponível em:

<http://portal.saude.gov.br/portal/arquivos/pdf/casos_febremaculosa_89_08.pdf>. Acesso em: 06 out. 2009.

BRASIL. Ministério da Saúde. Secretaria de Vigilância em Saúde. Número de óbitos por Rickettsioses. 2009b. Disponível em:

<http://portal.saude.gov.br/portal/arquivos/pdf/febremaculosa_obitos89_08.pdf>. Acesso em: 06 out. 2009. 
BRASIL. Ministério da Saúde. Secretaria de Vigilância em Saúde. Óbitos de Raiva Humana. 2009c. Disponível em:

<http://portal.saude.gov.br/portal/arquivos/pdf/OBITOS_RAIVA.pdf>. Acesso em: 06 out. 2009.

CALIC, S. B.; GALVÃO, M. A.; BACELLAR, F.; ROCHA, C. M. B. M.; MAFRA, C. L.; LEITE, R. C.; WALKER, D. H. Human ehrlichioses in Brazil: first suspect cases. The Brazilian Journal of Infectious Diseases, v. 8, n. 3, p. 259-262, 2004.

CARNIELI, P.; FAHL, W. D.; CASTILHO, J. G.; OLIVEIRA, R. N.; MACEDO, C. I.; DURYMANOVA, E.; JORGE, R. S. P.; MORATO, R. G.; SPÍNDOLA, R. O.; MACHADO, L. M.; UNGAR DE SÁ, J. E.; CARRIERI, M. L.; KOTAIT, I. Characterization of Rabies virus isolated from canids and identification of the main wild canid host in Northeastern Brazil. Virus Research, v. 131, n. 1, p. 33-46, 2008.

COMUNIDADE EUROPÉIA. CE. Regulation of the European Parliament and of the Council, capítulo III, artigo 8. 2003. Disponível em: <http://ec.europa.eu/food/animal/liveanimals/pets/annex2c_reg998_03_en.pdf>. Acesso em: 13 out 2009.

CHILDS, J. Epidemiology. In: JACKSON, A. C.; WUNNER, W. H. (Ed.). Rabies. San Diego: Academic Press, 2002. p. 113-161.

CHOMCZYNSKI, P. A reagent for the single-step simultaneous isolation of RNA, DNA and proteins from cell and tissue samples. BioTechniques, v. 15, n. 3, p. 532-537, 1993.

CITES. Convention on International Trade in Endangered Species of Wild Fauna and Flora. CITES Appendices I, II and III, apêndice 1. 1975. Disponível em:

<http://www.cites.org/eng/resources/species.html>. Acesso em: 06 out. 2009.

CLEAVELAND, S.; LAURENSON, K.; FUNK, S.; PACKER, C. Impact of viral infections in wild carnivore populations. In: MORATO, R. G.; RODRIGUES, F. H. G.; EIZIRIK E.; MANGINI, P. R.; AZEVEDO, F. C. C.; MARINHO-FILHO, J. (Ed.). Manejo e conservação de carnívoros neotropicais. São Paulo: IBAMA, 2006. p. 326-349.

COSTA, P. S.; BRIGATTE, M. E.; GRECO, D. B. Questing one Brazilian query: reporting 16 cases of $Q$ fever from Minas Gerais, Brazil. Revista do Instituto de Medicina Tropical de São Paulo, v. 48, n. 1, p. 5-9, 2006. 
CREEL, S.; CREEL, N.; MUNSON, L.; SANDERLIN, D.; APPEL, M. Serosurvey for selected viral diseases and demography of African wild dogs in Tanzania. Journal of Wildlife Diseases, v. 33, n. 4, p. 823-832, 1997.

CRIADO-FORNELIO, A.; BULING, A.; CASADO, N.; GIMENEZ, C.; RUAS, J.; WENDT, L.; ROSA-FARIAS, N.; PINHEIRO, M.; REY-VALEIRON, C.; BARBACARRETERO, J. C. Molecular characterization of arthropod-borne hematozoans in wild mammals from Brazil, Venezuela and Spain. Acta Parasitologica, v. 54, n. 3, p. 187-193, 2009.

CRIADO-FORNELIO, A.; BULING, A.; CUNHA-FILHO, N. A.; RUAS, J. L.; FARIAS, N. A. R.; REY-VALEIRON, C.; PINGRET, J. L.; ETIEVANT, M.; BARBA-

CARRETERO, J. C. Development and evaluation of a quantitative PCR assay for detection of Hepatozoon sp. Veterinary Parasitology,v. 150, n. 4, p. 352-356, 2007.

CUNNINGHAM, A. A. A walk on the wild side - emerging wildlife diseases: they increasingly threaten human and animal health. British Medical Journal, v. 331, p. 214-215, 2005.

CURRIER, M.; RUSSELL, K. Hematology and blood chemistry of the mountain lion (Felis concolor). Journal of Wildlife Diseases, v. 18, n. 1, p. 99-104, 1982.

DASZAK, P.; CUNNINGHAM, A. A.; HYATT, A. D. Emerging infectious diseases of wildlife - threats to biodiversity and human health. Science, v. 287, p. 443-449, 2000.

DEEM, S. L.; DAVIS, R.; PACHECO, L. F. Serologic evidence of nonfatal rabies exposure in a free-ranging oncilla (Leopardus tigrinus) in Cotapata National Park, Bolivia. Journal of Wildlife Diseases, v. 40, n. 4, p. 811-815, 2004.

DOYLE, C. K.; LABRUNA, M. B.; BREITSCHWERDT, E. B.; TANG, Y. W.; CORSTVET, R. E.; HEGARTY, B. C.; BLOCH, K. C.; LI, P.; WALKER, D. H.; MCBRIDE, J. W. Detection of Medically Important Ehrlichia by Quantitative Multicolor TaqMan Real-Time Polymerase Chain Reaction of the dsb Gene. Journal of Molecular Diagnostics, v. 7, n. 4, p. 504-510, 2005.

DUNBAR, M.; NOL, P.; LINDA, S. Hematologic and serum biochemical reference intervals for Florida panthers. Journal of Wildlife Diseases, v. 33, n. 4, p. 783-789, 1997.

DUPUIS, G.; PETITE, J.; PETER, O.; VOUILLOZ, M. An important outbreak of human $Q$ fever in a Swiss alpine valley. International Journal of Epidemiology, $v$. 16, p. 282-287, 1987. 
DURDEN, L. A.; CUNNINGHAM, M. W.; MCBRIDE, R.; FERREE, B. Ectoparasites of free-ranging pumas and jaguars in the Paraguayan Chaco. Veterinary Parasitology, v. 137, p. $189-193,2006$.

EAST, M. L.; HOFER, H.; COX, J. H.; WULLE, U.; WIIK, H.; PITRA, C. Regular exposure to rabies virus and lack of symptomatic disease in Serengeti spotted hyenas. Proceedings of the National Academy of Sciences of the United States of America, v. 98, n. 26, p. 15026-15031, 2001.

EWING, S.A.; PANCIERA, R. J. American canine hepatozoonosis. Clinical Microbiology Reviews, v. 16, p. 688-697, 2003.

FARFÁN-ALE, J. A.; BLITVICH, B. J.; MARLENEE, N. L.; LOROÑO-PINO, M. A.; PUERTO-MANZANO, F.; GARCÍA-REJÓN, J. E.; ROSADO-PAREDES, E. P.; FLORES-FLORES, L. F.; ORTEGA-SALAZAR, A.; CHÁVEZ-MEDINA, J.; CREMIEUX-GRIMALDI, J. C.; CORREA-MORALES, F.; HERNÁNDEZ-GAONA, G.; MÉNDEZ-GALVÁN, J. F.; BEATY, B. J. Antibodies to West Nile virus in asymptomatic mammals, birds, and reptiles in the Yucatan Peninsula of Mexico. The American Journal of Tropical Medicine and Hygiene, v. 74, n. 5, p. 908-914, 2006.

FARREL, L. E.; ROMAN, J.; SUNQUIST, M.E. Dietary separation of sympatric carnivores identified by molecular analysis of scats. Molecular Ecology, v. 9, p. 1583-1590, 2000.

FAVORETTO, S. R.; CARRIERI, M. L.; TINO, M. S.; ZANETTI, C. R. \& PEREIRA, O. A. C. - Simplified fluorescent inhibiton microtest for the titration of rabies neutralizing antibodies. Revista do Instituto de Medicina Tropical de São Paulo, v. 35, p. 171175, 1993.

FULLER, T.; KERR, K.; KARNS, P. Hematology and serum chemistry of bobcats in northcentral Minnesota. Journal of Wildlife Diseases, v. 21, n. 1, p. 29-32, 1985.

FUNK, S. M.; FIORELLO, C. V.; CLEAVELAND, S.; GOMPPER, M. E. The role of disease in carnivore ecology and conservation. In: GITTLEMAN J. L.; FUNK, S. M.; MACDONALD, D. W.; WAYNE, R.K. (Ed.). Carnivore conservation. 2. ed. Cambridge, UK: Cambridge University Press, 2001. p. 443-466.

GASCOYNE, S. C.; LAURENSON, M. K.; LELO, S.; BORNER, M. Rabies in African wild dogs (Lycaon pictus) in the Serengeti region, Tanzania. Journal of Wildlife Diseases, v. 29, p. 396-402, 1993. 
GRATZ, N. G. Emerging and resurging vector-borne diseases. Annual Review of Entomology, v. 44, p. 51-75, 1999.

HAWKEY, C.; HART, M. Haematological reference values for adult pumas, lions, tigers, leopards, jaguars and cheetahs. Research in Veterinary Science, v. 41, n. 2, p. 268-269, 1986.

HEIDRICH, J.; SCHÖNBERG, A.; STEUBER, S.; NÖCKLER, K.; SCHULZE, P.; VOIGT, W. P.; SCHEIN, E. Investigation of skin samples fromred foxer (Vulpes vulpes) in eastern Bradenburg (Germany) for the detection of Borrelia burgdorferi s. I. Zentralblatt für Bakteriologie, v. 289, p. 666-672, 1999.

HILL, R.; BERAN, G.; CLARK, W. Demonstration of rabies virus-specific antibody in the sera of free-ranging lowa raccoons (Procyon lotor). Journal of Wildlife Diseases, v. 28, n. 3, p. 377-385, 1992.

HOPE, K.; DEEM, S. L. Retrospective study of morbidity and mortality of maptive jaguars (Panthera onca) in North America: 1982-2002. Zoo Biology, v. 25, p. 501512, 2006.

HORTA, M. C.; CHIEBAO, D. P.; SOUZA, D. B.; FERREIRA, F.; PINHEIRO, S. R.; LABRUNA, M. B.; SCHUMAKER, T. T. Prevalence of Rickettsia felis in the fleas Ctenocephalides felis felis and Ctenocephalides canis from two Indian villages in Sao Paulo Municipality, Brazil. Annals of the New York Academy of Sciences, v. 1078, p. 361-363, 2006.

IUCN. International Union for the Conservation Of Nature. IUCN Red List of threatened species: Panthera onca, 2002. Disponível em: <www.iucnredlist.org>. Acesso em: 01 fev. 2008.

JACKSON, C. B.; FISHER, T. Fatal cytauxzoonosis in a Kentucky cat (Felis domesticus). Veterinary Parasitology, v. 139, p. 192-195, 2006.

JORGE, R. S. P. Caracterização do estado sanitário dos carnívoros selvagens da RPPN SESC Pantanal e de animais domésticos da região. 2008. 105p. Tese (Doutorado) - Faculdade de Medicina Veterinária e Zootecnia, Universidade de São Paulo, São Paulo, 2008.

KENNEDY, M.; CITINO, S.; MCNABB, A. H.; MOFFATT, A. S.; GERTZ, K.; KANIA, S. 
Detection of feline coronavirus in captive Felidae in the USA. Journal of Veterinary Diagnostic Investigation, v. 14, n. 6, p. 520-522, 2002.

KISSUI, B. M.; PACKER, C. Top-down regulation of a top predator: lions in the Ngorongoro Crater. Proceedings of the Royal Society of London - Series B: Biological Sciences, v. 271, p. 1867-1874, 2004.

KOCAN, A; BLOUIN, E. Hematologic and serum chemical values for free-ranging bobcats, Felis rufus (Schreber), with reference to animals with natural infections of Cytauxzoon felis Kier, 1979. Jounal of Wildlife Diseases, v. 21, n. 2, p. 190-192, 1985.

LABRUNA, M. B.; JORGE, R. S.; SANA, D. A.; JÁCOMO, A. T. A.; KASHIVAKURA, C. K.; FURTADO, M. M.; FERRO, C.; PEREZ, S. A.; SILVEIRA, L.; SANTOS, J. R.; TARCÍSIO, S.; MARQUES, S. R.; MORATO, R. G.; NAVA, A.; ADANIA, C. H.; TEIXEIRA, R. H. F.; GOMES, A. A. B.; CONFORTI, V. A.; AZEVEDO, F. C. C.; PRADA, C. S.; SILVA, J. C. R.; BATISTA, A. F.; MARVULO, M. F. V.; MORATO, R. L. G.; ALHO, C. J. R.; PINTER, A.; FERREIRA, P. M.; FERREIRA, F.; BARROSBATTESTI, D. M. Ticks (Acari: Ixodida) on wild carnivores in Brazil. Experimental and Applied Acarology, v. 36, p. 149-163, 2005.

LABRUNA, M. B.; PACHECO, R. C.; RICHTZENHAIN, L. J.; SZABÓ, M. P. Isolation of Rickettsia rhipicephali and Rickettsia bellii from Haemaphysalis juxtakochi ticks in the state of São Paulo, Brazil. Applied and Environmental Microbiology, v. 73, n. 3, p. 869-873, 2007.

LABRUNA, M. B.; WHITWORTH, T.; HORTA, M.; BOUYER, D. H.; MCBRIDE, J. W.; PINTER, A.; POPOV, V.; GENNARI, S. M.; WALKER, D. H. Rickettsia species infecting Amblyomma cooperi ticks from an area in the State of São Paulo, Brazil, where Brazilian spotted fever is endemic. Journal of Clinical Microbiology, v. 42, n. 1, p. 90-98, 2004.

LEPIDI, H.; BUNNELL, J. E.; MARTIN, M. E.; MADIGAN, J. E.; STUEN, S.; DUMLER, J. S. Comparative pathology, and immunohistology associated with clinical illness after Ehrlichia phagocytophila-group infections. The American Journal of Tropical Medicine and Hygiene, v. 62, n. 1, p. 29-37, 2000.

LINARDI, P. M.; GUIMARÃES, L. R. Sifonápteros do Brasil. São Paulo: Museu de Zoologia USP/FAPESP, 2000. 291p.

LLOYD, S. Environmental influences on host immunity. In: GRENFELL, B. T.; DOBSON, A. P. (Ed.). Ecology of infectious diseases in natural populations. 
Cambridge: Cambridge University Press, 1995. p. 327-361.

MACDONALD, D. W.; KAYS, R. W. Carnivores of the world: an introduction. In: NOWAK, R. M. (ed). Walker's carnivores of the world. Baltimore: Johns Hopkins University Press, 2005. p. 1-67.

MACHADO, R. Z.; DUARTE, J. M. B.; DAGNONE, A. S.; SZABÓ, M. P. J. Detection of Ehrlichia chaffeensis in Brazilian marsh deer (Blastocerus dichotomus). Veterinary Parasitology, v. 139, p. 262-266, 2006.

MARRIE, T. J. Epidemiology of $Q$ fever. In: MARRIE, T. J. (ed.). Q fever, the disease. Estados Unidos: CRC Press Inc., 1990. v. 1, p. 49-70.

MAURIN, M.; RAOULT, D. Q fever. Clinical Microbiology Reviews, v. 12, n. 4, p. 518-53, 1999.

MEIER, H. T.; MOORE, L. E. Feline cytauxzoonosis: a case report and literature review. Journal of the American Animal Hospital Association, v. 36, n. 6,p. 493496, 2000.

METZGER, B.; PADUAN, K. S.; RUBINI, A. S.; OLIVEIRA, T. G.; PEREIRA, C.; O'DWYER, L. H. The first report of Hepatozoon sp. (Apicomplexa: Hepatozoidae) in neotropical felids from Brazil. Veterinary Parasitology, v. 152, p. 28-33, 2008.

MILLER, B.; RABINOWITZ, A. Por que conservar al jaguar? In: MEDELLIN, R. A.; CHETKIEWICZ, C.; RABINOWITZ, A.; REDFORD, K. H.; ROBINSON, J. G.; SANDERSON, E.; TABER, A. (Ed.). Jaguars in the new millennium: a status assessment, priority detection, and recommendations for the conservation of jaguars in the Americas. Mexico, D. F.: UNAM/WCS, 2002. p. 303-315.

BRASIL. Ministério do Meio Ambiente. MMA. Lista nacional das espécies da fauna brasileira ameaçadas de extinção. Diário Oficial da União, Brasília, 22 maio 2003. Disponível em: <http://www.mma.gov.br/port/sbf/fauna/index.cfm>. Acesso em: 01 fev. 2008.

MONDOLFI, E.; HOOGESTEIJN, R. Notes on the biology and status of the jaguar in Venezuela. In: MILLER, S. D.; EVERETT, D. D. (Ed.) Cats of the world: biology, conservation, and management. Washington, D.C.: Nat. Wildl. Fed., 1986. 501p. 
método para contenção e para obtenção de sêmen, caracterização do ejaculado, biometria testicular, níveis séricos de testosterona e sazonalidade. 1997. 120 p. Dissertação (mestrado) - Faculdade de Medicina Veterinária e Zootecnia, Universidade de São Paulo, 1997.

MUNSON, L.; TERIO, K. A.; KOCK, R.; MLENGEYA, T.; ROELKE, M. E.; DUBOVI, E.; SUMMERS, B.; SINCLAIR, A. R. E.; PACKER, C. Climate extremes promote fatal co-infections during canine distemper epidemics in African lions. PloS One, v. 3, n. 6, p. e2545, 2008.

MURRAY, D. L.; KAPKE, C. A.; EVERMANN, J. F.; FULLER, T. K. Infectious disease and the conservation of free-ranging large carnivores. Animal Conservation, v. 2, n. 4, p. 241-254, 1999.

NAKA, E. N.; COSTA, I. P.; ARÃO, C. A.; SOARES, C. O.; YOSHINARI, N. H. Pesquisa de anticorpos anti-Borrelia e anti-Babesia em soro de crianças com manifestações clínicas e epidemiologia compatíveis com a doença de Lyme-Simile no Estado de Mato Grosso do Sul. Revista Brasileira de Reumatologia, v. 48, n. 2, p. 74-85, 2008.

NAVA, A. F.; CULLEN, L.; SANA, D. A., NARDI, M. S.; RAMOS-FILHO, J. D.; LIMA, T. F.; ABREU, K. C.; FERREIRA, F. First evidence of canine distemper in Brazilian free-ranging felids. EcoHealth, v. 5, n. 4, p. 513-518, 2008.

NIETFELD, J. C.; POLLOCK, C. Fatal cytauxzoonosis in a free-ranging bobcat (Lynx rufus). Journal of Wildlife Diseases, v. 38, n. 3, p. 607-10, 2002.

O'BRIEN, S.; ROELKE, M.; MARKER, L.; NEWMAN, A.; WINKLER, C. A.; MELTZER, D.; COLLY, L.; EVERMANN, J. F.; BUSH, M.; WILDT, D. E. Genetic basis for species vulnerability in the cheetah. Science, v. 227, n. 4693, p. 1428-1434, 1985.

PACHECO, R. C.; HORTA, M. C.; MORAES-FILHO, J.; ATALIBA, A. C.; PINTER, A.; LABRUNA, M. B. Rickettsial infection in capybaras (Hydrochoerus hydrochaeris) from São Paulo, Brazil: serological evidence for infection by Rickettsia bellii and Rickettsia parkeri. Biomédica, v. 27, p. 364-371, 2007.

PADDOCK, C. D.; FINLEY, R. W.; WRIGHT, C. S.; ROBINSON, H. N.; SCHRODT, B. J.; LANE, C. C.; EKENNA, O.; BLASS, M. A.; TAMMINGA, C. L.; OHL, C. A.; MCLELLAN, S. L. F.; GODDARD, J.; HOLMAN, R. C.; OPENSHAW, J. J.; SUMNER, J. W.; ZAKI, S. R.; EREMEEVA, M. E. Rickettsia parkeri rickettsiosis and its clinical distinction from Rocky Mountain spotted fever. Clinical Infectious Diseases, v. 47, 
p. 1188-1196, 2008.

PAROLA, P.; LABRUNA, M. B.; RAOULT, D. Tick-borne rickettsioses in America: unanswered questions and emerging diseases. Current Infectious Disease Reports, v. 11, p. 40-50, 2009.

PAROLA, P.; RAOULT, D. Ticks and tickborne bacterial diseases in humans: an emerging infectious threat. Clinical Infectious Diseases, v. 32, n. 6, p. 897-928, 2001.

SÃO PAULO (estado). Instituto Pasteur de São Paulo. Dosagem de anticorpos anti-rábicos em humanos. Disponível em:

<http://www.pasteur.saude.sp.gov.br/anticorpos/anticorpos_01.htm>. Acesso em 13 de outubro de 2009.

PATTON, S.; RABINOWITZ, A.; RANDOLPH, S.; JOHNSON, S. A coprological survey of parasites of wild neotropical felidae. The Journal of Parasitology, v. 72, n. 4, p. 517-520, 1986.

PEIXOTO, P. V.; SOARES, C. O.; SCOTFIELD, A.; SANTIAGO, C. D.; FRANÇA, T. N.; BARROS, S. S. Fatal cytauxzoonosis in captive-reared lions in Brazil.

Veterinaray Parasitology, v. 145, p. 383-387, 2007.

PINTER, A.; LABRUNA, M. B. Isolation of Rickettsia rickettsii and Rickettsia bellii in cell culture from the tick Amblyomma aureolatum in Brazil. Annals of the New York Academy of Sciences, v. 1078, p. 523-529, 2006.

PINTER, A.; HORTA, M. C.; PACHECO, R. C.; MORAES-FILHO, J.; LABRUNA, M. $B$. Serosurvey of Rickettsia sp. in dogs and humans from an endemic area for Brazilian spotted fever in the State of São Paulo. Cadernos de Saúde Pública, v. 24, n. 2, p. 247-252, 2008.

QUIGLEY, H.; CRAWSHAW-JÚNIOR, P. G. A conservation plan for the jaguar Panthera onca in the Pantanal region of Brazil. Biological Conservation, v. 61, n. 3, p. 149-157, 1992.

RAMOS-SILVA, J. C.; MARVULO, M. F.; DIAS, R. A.; FERREIRA, F.; AMAKU, M.; ADANIA, C. H.; FERREIRA-NETO, J. S. Risk factors associated with sero-positivity to Toxoplasma gondii in captive neotropical felids from Brazil. Preventive Veterinary Medicine, v. 78, p. 286-295, 2007. 
RAOULT, D.; LEVY, P. Y.; HARLÉ, J. R.; ETIENNE, J.; MASSIP, P.; GOLDSTEIN, F.; MICOUD, M.; BEYTOUT, J.; GALLAIS, H.; REMY, G.; CAPRON, J. P. Chronic Q fever: diagnosis and follow-up. Annals of the New York Academy of Sciences, v. 590, p. 51-60, 1990.

RAOULT, D.; ROUX, V. Rickettsioses as paradigms of new or emerging infectious diseases. Clinical Microbiology Reviews, v. 10, n. 4, p. 694-719, 1997.

RAWLINS, S. C.; ALEXANDER, F. C.; MOE, V; CAESAR, E.; MOLL, K.; APPLEWHAITE, L. Screwworm (Diptera: Calliphoridae) myiasis in the Southern Caribbean, and proposals for its management. Journal of Economic Entomology, v. 76, n. 5, p. 1107-1111, 1983.

REEVES, W. K.; LOFTIS, A. D.; SANDERS, F.; SPINKS, M. D.; WILLS, W.; DENISON, A. M.; DASCH, G. A. Borrelia, Coxiella, and Rickettsia in Carios capensis (Acari: Argasidae) from a brown pelican (Pelecanus occidentalis) rookery in South Carolina, USA. Experimental \& Applied Acarology, v. 39, p. 321-329, 2006.

REGNERY, R. L.; SPRUIL, C. L.; PLIKAYTIS, B. D. Genotypic identification of rickettsiae and estimation of intraspecies sequence divergence for portion of two rickettsial genes. Journal of Bacteriology, v. 173, p. 1576-1589, 1991.

RIVETTI-JÚNIOR, A. V. Retroviroses, Toxoplasma gondii e Mycoplasma haemofelis em gatos errantes e felinos selvagens do zoológico de Belo Horizonte - MG. 2006. 38p. Dissertação (mestrado) - Escola de Veterinária, Universidade Federal de Minas Gerais, Belo Horizonte, 2006.

ROELKE-PARKER, M.; MUNSON, L.; PACKER, C.; KOCK, R.; CLEAVELAND, S.; CARPENTER, M.; O'BRIEN, S. J.; POSPISCHIL, A.; HOFMANN-LEHMANN, R.; LUTZ, H.; MWAMENGEL, G. L. A.; MGASA, M. N.; MACHANGE, G. A.; SUMMERS, B. A.; APPEL, M. J. G. A canine distemper virus epidemic in Serengeti lions (Panthera leo). Nature, v. 379, p. 441-445, 1996.

SAITO, T. B.; CUNHA-FILHO, N. A.; PACHECO, R. C., FERREIRA, F.; PAPPEN, F. G.; FARIAS, N. A. R. LARSSON, C. E.; LABRUNA, M. B. Canine infection by rickettsiae and ehrlichiae in southern Brazil. The American Journal of Tropical Medicine and Hygiene, v. 79, n. 1, p. 102-108, 2008.

SCHMITT, A.; REISCHAK, D.; CAVLAC, C. L.; MONFORTE, C. H. L.; COUTO, F. T.; ALMEIDA, A. B. P. F.; GRAZIELE, D.; SANTOS, D. G. G.; SOUZA, L.; ALVES, C.; VECCHI, K. Infecção pelos vírus da leucemia felina e da peritonite infecciosa felina 
em felídeo selvagem de vida livre e de cativeiro da região do Pantanal matogrossense. Acta Scientiae Veterinariae, v. 31, n. 3, p. 185-188, 2003.

SEYMOUR, K. Panthera onca. Mammalian Species, v. 340, p. 1-9, 1989.

SICILIANO, R.; RIBEIRO, H.; FURTADO, R.; CASTELLI, J. B.; SAMPAIO, R. O.; SANTOS, F. C. P.; COLOMBO, S.; GRINBERG, M.; STRABELLI, T. M. V. Endocardite por Coxiella burnetii (febre Q): doença rara ou pouco diagnosticada? Relato de caso; Endocarditis due to Coxiella burnetii ( $Q$ fever): a rare or little diagnosed disease? Case report. Revista da Sociedade Brasileira de Medicina Tropical, v. 41, n. 4, p. 409-412, 2008.

SILLERO-ZUBIRI, C.; KING, A.; MACDONALD, D. Rabies and mortality in Ethiopian wolves (Canis simensis). Journal of Wildlife Diseases, v. 32, n. 1, p. 80-86, 1996.

SILVEIRA, I.; PACHECO, R. C.; SZABO, M. P.; RAMOS, H. G.; LABRUNA, M. B. Rickettsia parkeri in Brazil. Emerging Infectious Diseases, v. 13, p. 1111-1113, 2007.

SMITH, T. G. The genus Hepatozoon (Apicomplexa: Adeleina). The Journal of Parasitology, v. 82, n. 4, p. 565-85, 1996.

SOUZA, S. S.; SOUZA, C. E.; RODRIGUES-NETO, E. J.; PRADO, A. P. Dinâmica sazonal de carrapatos (Acari: Ixodidae) na mata ciliar de uma área endêmica para febre maculosa na região de Campinas, São Paulo, Brasil. Ciência Rural, v. 36, n. 3, p. 887-891, 2006.

SPOLIDORIO, M. G.; LABRUNA, M. B.; ZAGO, A. M.; DONATELE, D. M.; CALIARI, K. M.; YOSHINARI, N. H. Hepatozoon canis infecting dogs in the State of Espírito Santo, Southeastern Brazil. Veterinary Parasitology, v. 163, n. 4, p. 357-361, 2009.

STEERE, A.; COBURN, J.; GLICKSTEIN, L. The emergence of Lyme disease. American Society for Clinical Investigation, v. 113, n. 8, p. 1093-1101, 2004.

STOEBEL, K.; SCHOENBERG, A.; STREICH, W. J. The seroepidemiology of Lyme borreliosis in zoo animals in Germany. Epidemiology and Infection, v. 131, n. 2, p. 975-983, 2003.

STROMDAHL, E.; WILLIAMSON, P.; KOLLARS, T.; EVANS, S. R.; BARRY, R. K.; VINCE, M. A.; DOBBS, N. A. Evidence of Borrelia lonestari DNA in Amblyomma 
americanum (Acari: Ixodidae) removed from humans. Journal of Clinical Microbiology, v. 41, n. 12, p. 5557-5562, 2003.

THRALL, A. M. Hematologia e bioquímica clínica veterinária. 1. ed. São Paulo: Editora Roca, 2007. 592p.

ULLREY, D. E. Nutrition and predisposition to infectious disease. Journal of Zoo and Wildlife Medicine, v. 24, p. 304-314, 1993.

VENZAL, J. M.; ESTRADA-PEÑA, A.; CASTRO, O.; SOUZA, C. G.; FÉLIX, M. L.; NAVA, S.; GUGLIELMONE, A. A. Amblyomma triste Koch, 1844 (Acari: Ixodidae): hosts and seasonality of the vector of Rickettsia parkeri in Uruguay. Veterinary Parasitology, v. 155, p. 104-109, 2008.

WIDMER, C. E.; AZEVEDO, F. C. C. Tungíase em onças-pintadas (Panthera onca) de vida livre no Pantanal Sul - MS. In: ENCONTRO INTERNACIONAL DE MEDICINA DA CONSERVAÇÃO, 2, 2009, Recife, PE. Anais...2009. Disponível em: <http://www.eventoexpress.com.br/cdiieimc/pdf/60.pdf>. Acesso em: 02 nov. 2009.

WILLIAMS, E. S.; YUILL, T.; ARTOIS, M.; FISCHER, J.; HAIGH, S. A. Emerging infectious diseases in wildlife. Revue Scientifique et Technique (International Office of Epizootics), v. 21, n. 1, p. 139-157, 2002.

YOSHINARI, N. H.; ABRÃO, M. G.; BONOLDI, V. L.; SOARES, C. O.; MADRUGA, C. R.; SCOFIELD, A.; MASSARD, C. L.; FONSECA, A. H. Coexistence of antibodies to tick-borne agents of babesiosis and Lyme borreliosis in patients from Cotia county, State of São Paulo, Brazil. Memórias do Instituto Oswaldo Cruz, Rio de Janeiro, v. 98, n. 3, p. 311-318, 2003. 


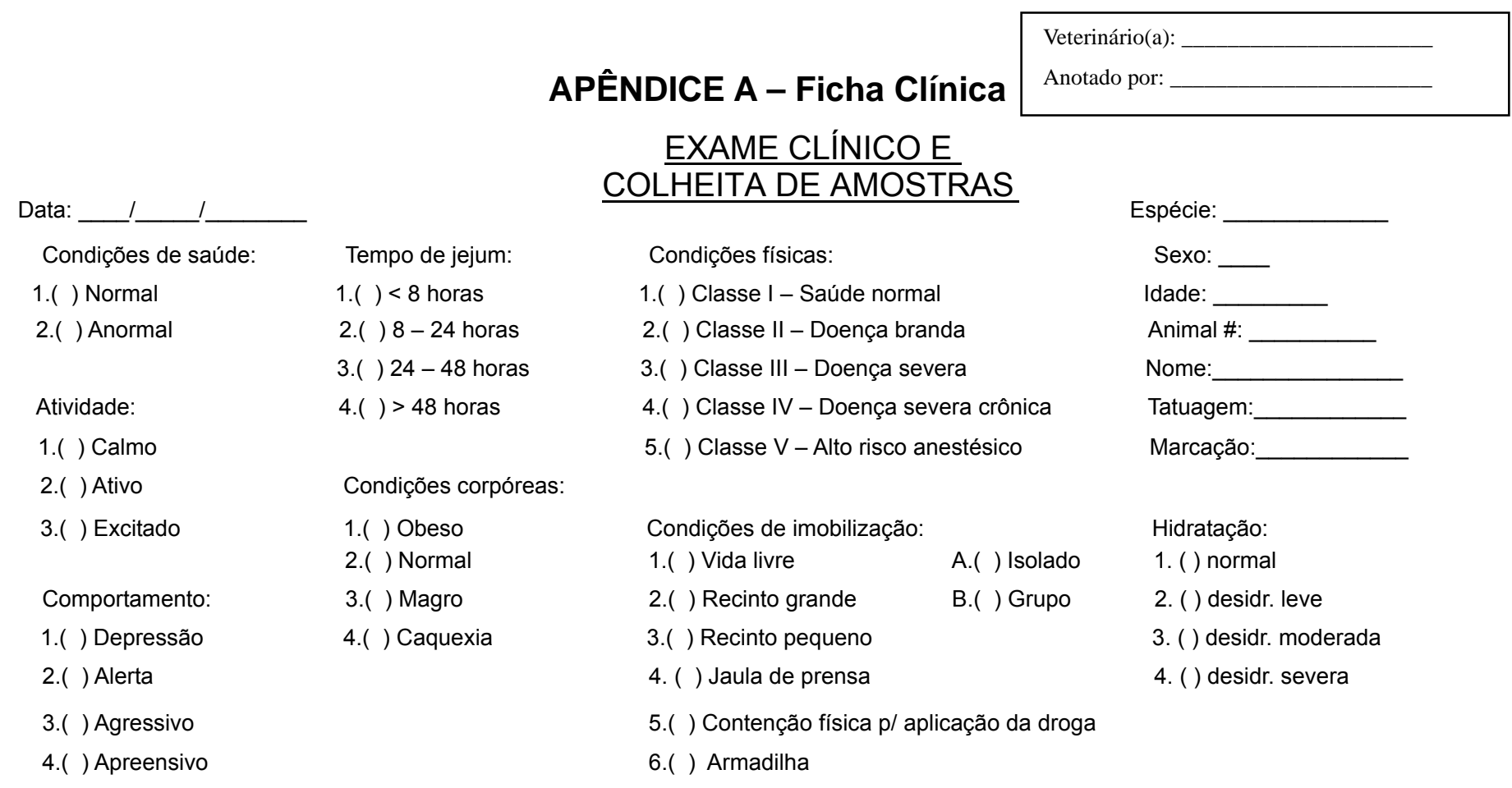

\section{OBSERVACÕES CLÍNICAS}
1. Mucosas: ( )hiperêmicas
( )normais
( )pálidas

2. Nariz/olhos/orelhas:

3. Boca: ( )normal

( )gengivite

( )fratura dente(

( )

4. Vagina/pênis/testículos/mamas:

5. Pele/pêlos: ( )normais

6. Feridas:( )não ( )sim

( )dermatite

( )sarna

( )antigas ( )novas ( )na captura

( )antigas ( )novas ( )na captura local:

8. Cicatrizes:( )não ( )sim

9. ( )Hepatomegalia

( )Esplenomegalia

( )Aumento renal ( )Direito ( )Esquerdo

( )

local:

local:

( Esplenomegalia

Outras observações:

\section{AMOSTRAS BIOLÓGICAS}

Contagem de ectoparasitas (3 minutos, coleta aleatória, preferência para cabeça, pescoço e dorso)

Total: Tipos:

Carrapatos ingurgitados (nifas e adultos) - manter vivos no frasco com papel seco.

Todos os não ingurgitados e pulgas (ou dúvida), colocar em um único frasco com álcool absoluto.

Amostras biológicas

\begin{tabular}{|l|l|l|l|}
\hline Tipo & N/Volume & Tipo & N/Volume \\
\hline Sangue+EDTA (tampa roxa $5 \mathrm{ml}$ ) -5 frascos & & Fezes na ampola retal & \\
\hline Sangue (tampa marrom 10 ml) - 4 frascos & & Swab mucosas: & \\
\hline Esfregaço sangüíneo - 1 lâmina & & Pêlos: \\
\hline Esfregaço sangue periférico - 1-3 lâminas & & Urina \\
\hline Biópsia de pele/local & & Citologia vaginal/Sêmen & \\
\hline Ectoparasitas (máx. possível) & Outras: & \\
\hline
\end{tabular}

Amostras sanguíneas: Entrega no laboratório: Separação amostras: 1 ( )natural ( ) centrífuga Congelamento: 1

( )freezer ( ) nitrogênio 